Şırnak Üniversitesi

Ilahiyat Fakültesi Dergisi

Cilt: 10, Sayı: 23, Aralık 2019

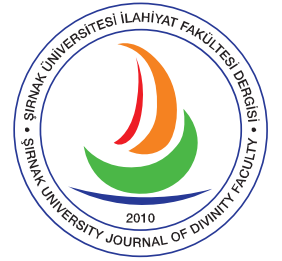

Şırnak University Journal of Divinity Faculty

Vol.: 10, Issue: 23, December 2019

e-ISSN 2667-6575

\title{
Ahkâm Âyetlerinin Tefsîrinde Mezhebe Bağlılık (Beydâvî ve Nesefî Örneği)
}

Adherence to the Sect in the Interpretation of Verses of the Rules (The Case of Baydawi and Nasafi)

\section{Mehmet BAĞIŞ}

Dr. Öğr. Üyesi, Şırnak Üniversitesi, İlahiyat Fakültesi, Tefsir Ana Bilim Dalı Assistant Professor Dr, Şırnak University, Faculty of Divinity, Department of Tafsir

Şırnak, Turkey

mbagiss@hotmail.com

https://orcid.org/0000-0002-5605-8813

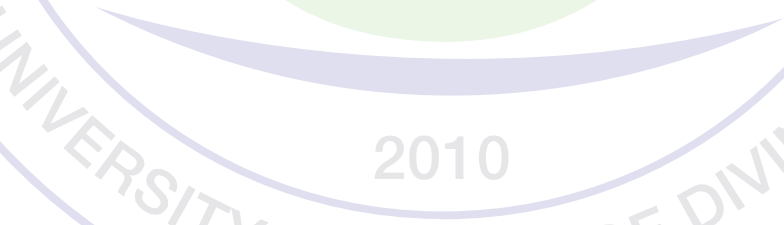

\section{Makale Bilgisi/ Article Information}

Makale Türü / Article Types: Araştırma Makalesi / Research Article

Geliş Tarihi / Received: 26 Temmuz / July 2019

Kabul Tarihi / Accepted: 18 Eylül / September 2019

Yayın Tarihi / Published: 15 Aralık / December 2019

Cilt / Volume: 10 Sayı / Issue: 23 Sayfa / Pages: 630-655

Atıf / Cite as: Bağış, Mehmet. "Ahkâm Âyetlerinin Tefsîrinde Mezhebe Bağlllık (Beydâvî ve Nesefî Örneği) [Adherence to the Sect in the Interpretation of Verses of the Rules (The Case of Baydawi and Nasafi)]". Şırnak Üniversitesi IIlahiyat Fakültesi DergisiŞırnak University Journal of Divinity Faculty 10/23 (December 2019): 630-655.

https://doi.org/10.35415/sirnakifd.597175

Copyright () Published by Şırnak Üniversitesi, İlahiyat Fakültesi / Şırnak, Türkiye (Şırnak University, Faculty of Divinity, Şırnak, 73000 Turkey). 
Öz

Kur'ân-1 Kerîm, kulların dünyevî ve uhrevî maslahatlarına yönelik birtakım fıkhî hükümler içermektedir. Tefsir kaynaklarımıza bakıldığında, Kur'ân'daki hükümlerle ilgili âyetleri özel olarak ele alan ve fikhî mezheplerin de görüşlerine değinmek suretiyle bu gibi âyetlerin tefsirini yapan birçok eser bulunmaktadır. "Ahkâm Âyetlerinin Tefsîrinde Mezhebe Bağlllık (Beydâvî ve Nesefî Örneği)" adlı bu çalışmamızda Beydâvî ve Nesefî̀nin, özellikle fürû-1 fıkıhla ilgili meselelerde ahkâm âyetlerini tefsir etme metotları üzerinde durulmuş, benzer ve farklı yönleri ortaya konulmaya çalışılmıştır. İki müfessir de kendi tefsirlerinde bu gibi konuları işlerken, genellikle müntesibi oldukları mezheplerinin görüşlerini tercih etmişlerdir. $\mathrm{Bu}$ görüşlerini ispatlamak maksadıyla da âyetlerden, hadislerden, icmâdan, kıyastan ve itibar edilen diğer delillerden yararlanmışlardır.

Hem Beydâvî'nin Envârü't-Tenzîl'inde hem de Nesefî'nin Medârikü'tTenzîl'inde ilk bakışta göze çarpan bir durum da bu iki tefsir eserinde Arap dili tahlillerine, belâgat inceliklerine ve ara sıra cahiliye şiirinden istişhatlara yer verilmesidir. İki tefsir eserinde mevcut olan bu ortak özellik, ahkâm âyetlerinin tefsirinde de görülmektedir.

Çalışmada; Besmele'nin Kur'ân'dan bir âyet olup olmadığı meselesi, kasr-1 salât, nikâh akdinde velî şartı ve kuru' meselesi gibi konular, Beydâvî ve Nesefî tefsirleri ekseninde detaylı olarak incelenmiştir.

Anahtar Kelimeler: Tefsir, Beydâvî, Nesefî, Ahkâm Âyetleri, Besmele, Kasr-1 salât, Nikâh, Velî.

\section{Abstract}

The Qur'an contains some fiqh (Islamic jurisprudence) provisions on worldly and ethereal affairs of man. Among tafsir sources, there are many works that particularly focus on verses about rules and deals with the interpretation of such verses by also referring to the views of the schools of fiqh. This study titled "Adherence to the Sect in the Interpretation of Verses of the Rules (The Case of Baydawi and Nasafi)" examined the methods of Baydawi and Nasafi to interpret verses of the rules concerning the matters of furu al-figh in particular and presented similarities and differences between them. While the two Mufassirs worked on such issues in their tafsirs, they generally preferred the views of the schools they were following. In order to prove these views, they have also benefited from the verses, hadiths, ijma, qiyâs and other evidences.

At first sight, in both Baydawi's Anvar al-Tanzil and Nasafi's Madarik alTanzil, a conspicuous case is that in these two tafsir works, Arab language analysis, eloquence of subtlety and occasional poetrical proofs from preislamic age of ignorance are included. This common feature, which is present in two pieces of tafsir, is also seen in the judgemental verses of tafsir. The study provided a detailed analysis of matters such as the question of whether basmala is a verse of the Qur'an, qasr salah, necessity of matrimonial guardianship and quru issue, based on the interpretation of Baydawi and Nasafi.

Keywords: Tafsir, Baydawi, Nasafi, Verses of the Rules, Basmala, Qasr alsalah, Marriage Contract, Parental Approval. 


\section{Extended Abstract}

The Qur'an contains some fiqh (Islamic jurisprudence) provisions on worldly and ethereal affairs of man. These are legal provisions that regulate man's relationship with his creator, with other people or society. Fiqh tafsir (juridical interpretation), addressing the practical dimension of the Qur'an, is a type of tafsir that explains verses of the rules (ayat al-ahkam) concerning ibadad (worship), muamalat (transactions-human relations) and uqubat (penalties), and tries to have rulings based on them. Among tafsir sources, there are many works that particularly focus on verses of the rules and deals with the interpretation of such verses by also referring to the views of the schools of fiqh. While some of these works only interpret ayat al-ahkam, some others give particular importance to such verses in their own interpretation.

This study titled "Adherence to the Sect in the Interpretation of Verses of the Rules (The Case of Baydawi and Nasafi)" examined the methods of Baydawi and Nasafi to interpret verses of the rules concerning the matters of furu al-figh in particular and presented similarities and differences between them. The study provided a detailed analysis of matters such as the question of whether basmala is a verse of the Qur'an, qasr salah, necessity of matrimonial guardianship and quru issue, based on the interpretation of Baydawi and Nasafi.

While addressing matters relating to furu al-figh in his Anwar al-Tanzil, Baydawi explained different views of the schools of Islam along with the evidences they proposed. He usually preferred the view of the Shafi'i school of which he was a follower and compared it to view of the Hanafis. To prove his opinions on fiqh issues, he often referred to the in the Qur'an, hadith, ijma (consensus), comparison and other credited evidences.

In a similar vein, Nasafi dealt with subjects falling within the scope of fiqh in various part of his commentary Madarik al-Tanzil and attempted to provide evidences for the views of the Hanafi School, of which he was a follower, by referring to the verses. As for matters relating to furu al-figh, he criticized the views of the Shafi'i school, in an attempt to show that the views of the Hanafi school were more accurate Nasafî also sometimes dealt with the fiqh disputes taken place among the students of Ebû Haniffe. At first sight, in both Anwar al-Tanzil and in Madarik al-Tanzil, a conspicuous case is that in these two tafsir works, Arab language analysis, eloquence of subtlety and occasional poetrical proofs from pre-islamic age of ignorance are included. This common feature, which is present in two pieces of tafsir, is also seen in the judgemental verses of tafsir. One of the topics in this study, Baydâwî expressed about whether Basmala is a verse or not in the Qur'an, including Surah Fatiha and he said that Basmala coming from every surah was a separate verse belonging to that surah. In order to prove his opinion, he first gave the hadiths which will have evidential value, and then he mentioned that either two Mushaf covers were the words of Allah or the scholars should be very meticulous and ally with each other in this regard in order to prevent the things not present in the Qur'an into entering the Qur'an. In his opinion, in spite of this sensitivity of the scholars, if Basmala was written in all the Mushafs, Basmala is a verse from the Qur'an. 
In parallel with the opinion of the Hanafî sect, Nasafî claimed that both Fâtihâ and Basmala, which were among the other surahs, were not verses, but were separated from the surahs and written to Mushaf for teberrük. In order to prove his point, Nafasi commentated a hadith narrated from Abu Hurayrah (r.a). According to this hadith, the verse of al-Fatiha begins with the verse "Elhamdülillâhi Rabbi'l-âlemîn".

Regarding the shortening of the prayer in the journey, Beydavi saw the shortening as permissible and evaluated this provision on the license issue. In his opinion, Nisâ: 4/101 in the verse, "When you go on expedition on the earth, there is no sin for you to shorten the prayer" and it is not understood that the shortening of the prayer is necessary (vacip) from that expression. As evidence to his aspect, Baydawi alleged the hadith by approving, "When Aisha was with Rasûlullah (pbuh) on the umrah, she said "Yâ Rasûlallah! I sometimes shortened the prayers, sometimes I made it full, sometimes I fasted and sometimes did not fast"said by approving the Messenger of Allah (pbuh) "You did well, Yâ Aisha". In the interpretation of this verse, Nasafî proved and gave evidence with hadiths by prefering the opinion of the Hanafi sect, the accuracy of this view of the Prophet, the hadith reported from Omar, According to the prophet's informing, "The expedition prayers, without shortening, are exactly two rakaahs and this (shortening) is a charity (alms)given to you by God (c.c). Accept his charity." Opposing these narrations put forward by the Hanafis, Beydawi said that the expression of the verse clearly implies the license and that these narratives must be interpreted.

In the same way, in the marriage contract, defending the need for parental consent for the woman, Beydavî interpreted in the direction of his sect in the al-Bakara, 2/230, 232, 234 and en-Nisa, 4/25 verses. The most powerful evidence of this subject is al-Bakara, 2/232 is the narration of the sending down reason. According to this rumor Maetekil b. A gatherer called Yesar was blocking her sister from being divorced from her husband by rhetoric and with wanting to go back again. According to a rumour, a companion called Ma'kil b. Yesar's sister divorcing from her husband by Talaaq-e-Raji (Revocable Divorce) and wanted to come bact to her husband was obstructed by Ma'kil b. Yesar. For this reason, this verse was sent down. Ma'kil B. Yesar consented their marriage. In Baydawî's opnion, in the verse for parents the expression related to "Do not interfere with their marriage" is a proof that the woman will not solemnize her own marriage. Nasafî commented these verses in accordance with opinion of Hanafî sect and stated that there was no need for permission of the parents in marriage.

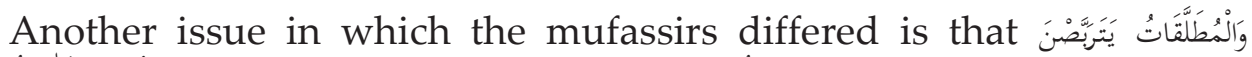
“Divorced women themselves wait for three quru (Baqara, 2/228)". It is about quru word meanings which are mentioned in Surah Baqara in the verses of 2,228. In accordance with the opinion of the Shafi>i sect, Baydâwî expressed this word is in the sense of tuhr (cleansing period), while Nasafî claimed that this was in the sense of the menstruation period in the direction of the view of Hanafî sect. 


\section{GİRIş}

Kur'ân'ın bazı âyetleri kulların dünyevî ve uhrevî maslahatlarına yönelik bir takım fıkhî hükümler içermektedir. Ahkâm âyetleri olarak adlandırılan bu âyetlerde, kişinin Yaratıcısıyla ve diğer kişilerle olan ilişkilerine yönelik hükümler ele alınır.

Kur'ân-1 Kerîm'in, amel yani ibâdât, muâmelât ve ukûbât yönleriyle meşgul olan ve bu konularla ilgili âyetleri ${ }^{1}$ açıklayıp onlardan hükümler çıkarmaya çalışan tefsir dalına fıkhî tefsir denilmektedir. ${ }^{2}$ Bu anlamda Kur'ân'daki ahkâm âyetleri, fıkhî tefsirin konusunu teşkil eder. ${ }^{3}$ Ancak fıkhî tefsirin konusu sadece ahkâm ayetleri olmayıp, Kur'ân'ın fıkıh yönüyle ilgili olan bütün ayetlerdir. Bunlar sadece açık hüküm ifade eden ayetler değil, müfessirin dirayetine bağlı olarak faydalanılabilen her türlü ayet olabilir. ${ }^{4}$ F1khî tefsir metodunu benimseyen müfessirler genellikle ahkâm âyetlerinin tefsirinde, fıkıh ilminin usûl ve fürû konuları hakkında açıklamalarda bulunmuş ve bu konularla ilgili var olan görüşler üzerinde değerlendirmeler yapmışlardır.

Tefsir kaynaklarımıza bakıldığında, Kur'ân'daki ahkâm ayetlerini özel olarak ele alan ve fıkhî mezheplerin de görüşlerine değinmek suretiyle bu gibi ayetlerin tefsirini yapan birçok eser bulunmaktadır. Bunlara örnek olarak Mukatil b. Süleyman'ın (ö. 150/767) Tefsiru Hamsi Mieti Âyetin

1 Çalışmada geçen âyet meallerinde genellikle Komisyon tarafından hazırlanan ve Diyanet İşleri Başkanlığı Yayınları tarafından yayınlanan (Ankara: 2006) Kur'an-ı Kerim Meâli'ne başvurulmuştur.

2 İsmail Cerrahoğlu, Tefsir Tarihi (Ankara: Fecr Yayınları, 2014), 463; Demirci, Tefsir Tarihi, 234; Mevlüt Güngör, Kur'ân Tefsirinde Fikhi Tefsir Hareketi ve İlk Fikhi Tefsir (İstanbul: Kur'ân Kitaplı̆̆, 1996$), 51$.

3 Muhsin Demirci, Tefsir Tarihi, 8. Baskı (İstanbul: İFAV Yayınları, 2010), 234; Güngör, Kur'ân Tefsirinde Fikhi Tefsir Hareketi ve Ilk Fikhi Tefsir, 51.

4 Güngör, Kur'ân Tefsirinde Fıkhi Tefsir Hareketi, 51. 
mine'-Kur'an'1, İmâm Şâfiî (ö. 204/820) tarafından hazırlandığı kabul edilen ahkâmü'1-Kur'ân ile ilgili eser, Hanefî âlimlerinden Ebü'-Hasan Ali b. Mûsâ el-Kummî (ö. 305/917), Tahâvî (ö. 321/933) ve Cessâs' in (ö. 370/980) Ahkâmü̈l-Kur'ân'ları; Şâfiîler'den Ebû Sevr İbrâhim b. Hâlid el-Kelbî (ö. 240/854-55) ile Kiyâ el-Herrâsî'nin (ö. 504/1110) Ahkâmül-Kur'ân adlı eserleri; Mâlikîler'den İsmâil b. İshak el-Ezdî'nin (ö. 282/895) AhkâmülKur'ân'ı ile İbn Ebî Zemenîn diye meşhur olan Muhammed b. Abdillâh elMürrî'nin (ö. 399/1008) Müntehabül-Ahkâm'1 ve Ebû Bekir İbnü'l-Arabî'nin (ö. 543/1148) Ahkâmül-Kur'ân'1; Hanbelîler'den de Ebû Ya'lâ el-Ferrâ'nın (ö. 458/1065-66) Ahkâmü̈l-Kur'ân'1 gibi eserler sayılabilir. Son zamanlarda ise Muhammed Sıddık Hasan Han'ın (ö. 1307/1890) Neylül-Merâm Min Tefsîri Âyâti'l-Ahkâm'ı, Konyalı Mehmed Vehbi Efendi'nin Ahkâm-ı Kur'âniyye'si, Muhammed Ali es-Sâbûnî'nin Ravâiu'l-Beyân fì Tefsîri Âyâti'l-Ahkâm ve Celâl Yıldırım'ın Kur'ân Ahkâmı ve Mezheb İmâmlarının Görüş Farkları adlı çalışmaları da bu alanda yazılmış eserlerdendir. ${ }^{5}$ Kurtubî'nin (ö. 671/1272) el-Câmi li-Ahkâmil-Kur'ân adlı eseri ise aynı adı taşımakla birlikte sadece ahkâm âyetlerinin tefsirinden ibaret olmayıp daha çok ahkâma ağırlık veren umumi bir tefsirdir. ${ }^{6}$ Çalışma alanı olarak belirlediğimiz Beydâvî'nin (ö.685/1286) Envâru't-Tenzîl'i ile Nesefî'nin (ö. 710/1310) Medâriku't-Tenzîl adlı eserlerinde ise Kur'ân ayetlerinin bütünü tefsir edilmiş, ancak ahkâm ayetleri üzerinde detaylıca durulmuştur. Beydâvî ve Nesefî de kendi tefsirlerinde ahkâm âyetlerini açıklarken, genellikle mensup oldukları mezheplerin görüşlerini tercih etmiş; bu görüşlerini ispatlamak maksadıyla da ayetlerden, hadislerden, icmâdan, kıyastan ve diğer edille-i şer'iyyeden yararlanmışlardır.

\section{BEYDÂ VÎ VE NESEFî'NİN AHKÂM ÂYETLERİNI TEFSİR ETME METOTLARI}

\subsection{Beydâvî'nin Ahkâm Âyetlerini Tefsir Etme Metodu}

Abdullâh b. Ömer el-Beydâvî, Şîrâz yakınlarında yer alan Beydâ kasabasında dünyaya gelmiştir. ${ }^{7}$ Hayatının ilk yıllarını bu kasabada geçiren Beydâvî, daha sonra ailesiyle birlikte Şiraz'a gitmiştir. Burada babasından

\footnotetext{
5 Bk. Bedreddin Çetiner, "Ahkâmü'l-Kur'an", Türkiye Diyanet Vakfı İslâm Ansiklopedisi (İstanbul: TDV Yayınları, 1988), 1: 551-552; Yakup Yüksel, "Fıkhî Tefsir Geleneğinde "Ahkâm-1 Kur'aniyye"nin Yeri", Gümüşhane Üniversitesi İlahiyat Fakültesi Dergisi 4/8, (2015/4): 173-177.

6 Çetiner, "Ahkâmü'1-Kur'an", 1: 551-552.

7 Yâkût b. Abdillah el-Hamevî, Mu'cemül-Büldân (Beyrut: Dâr Sâdır, 1995), 1: 529; İbnü'1İmâd, Ebû'l-Felâh 'Abdü'l-Hayy b. Ahmed b. Muhammed, Şezerâtü'z-zeheb fi ahbâri men zeheb, thk. Mahmud el-Arnavût (Şâm: Dâru İbn Kesîr, 1406/1986), 7: 685.
} 
icâzet almış, ardından ehl-i sünnet âlimlerinden aklî ve naklî ilimleri tahsil etmiştir. ${ }^{8}$

Envâru't-tenzîl ve esrâru't-te'vîl adlı tefsir eseriyle temâyüz eden Beydâvî, aynı zamanda fikıh ve fıkıh usûlü alanlarında meşhur olmuştur. ${ }^{9} \mathrm{Bu}$ alanlarda kaleme aldığı el-Minhâc, Ğâyetül-kusvâ,, Şerhu'-Müntehab, Şerhu't-Tenbîh ve Şerhu'-Mahsûl gibi eserleri, onun bu yönüne delalet etmektedir. Bununla birlikte o, hem fikıh ve fikıh usûlüyle ilgili yazdığı eserlerden dolayı hem de Envâru't-tenzîl adlı tefsîrinde fıkhî meseleleri ele alırken Şâfiî mezhebini savunduğu için Sübkî (ö. 771/1370), Dâvûdî (ö. 945/1539 [?]) ve Kâdî Şuhbe (ö. 851/1448) gibi tabakât sahipleri tarafından, Şâfiî âlimleri arasında sayılmıştır." 10

Beydâvî, Envâru't-tenzîl adlı tefsirinde bazen fıkıh usûlüyle ilgili bazen de fürû-1 f 1 kha dair meselelerde değerlendirmeler yapmıştır. Ele aldığg 1 flkhî meseleye dair görüşünü genellikle kendi mezhebinin görüşü istikametinde ifade eden Beydâvî, bu görüşü ispatlamak maksadıyla da âyet, hadis, icmâ ve kıyas gibi şer-î delillerden yararlanmıştır. ${ }^{11}$

\subsection{Nesefî'nin Ahkâm Âyetlerini Tefsir Etme Metodu}

Hanefî mezhebinin âlimleri arasında sayılan Ebü'l-Berekât Hâfızüddîn Abdullah b. Ahmed b. Mahmûd en-Nesefî, Buhara yakınlarındaki Nesef şehrinde doğmuştur. ${ }^{12}$ Mâverâünnehir bölgesinin yetiştirdiği önemli âlimlerden birisi olan Nesefî, başta usûl ve fıkıh olmak üzere tefsir, kelâm ve hadis alanında temâyüz etmiş, bu alanlarda eserler yazmıştır. ${ }^{13}$ Onun eserleri, özellikle Hanefî ilim çevrelerinde ve medreselerde çok okutu-

8 Ebû Saîd Nâsiruddîn, Abdullâh b. Ömer el-Beydâvî, Gâyetül-kusvâ fî dirâyeti'l-fetvâ, thk. Ali Muhyiddîn Ali el-Karadâğî (Beyrut: Dâru'l-Beşâiri'l-İslâmiyye, 2007/1429), 1: 74-75.

9 Tâcüddîn Abdülvehhâb es-Sübkî, Tabakâtü'ş-Şâfi'iyyetil-kübrâ, thk. Mahmud Muhammed et-Tanâhî, Abdülfettâh Muhammed el-Hulv (B.y. Dâru'l-Hicr, 1413), 8: 157-158.

10 Sübkî, Tabakâtü'ş-Şâfi'iyyeti'-kübrâ, 8: 157-158; Şemsüddîn Muhammed b. Ali ed-Dâvûdî, Tabakâtü'l-müfessirîn (Beyrut: Dâru'l-Kütübi'l-i̇lmiyye, ts.), 1: 248; Kâdî Şuhbe, Takiyyüddîn Ebû Bekir b. Ahmed, Tabakâtü'ş-Şâffiiyye, thk. Hâfız Abdül'alîm Hân, Âllemü'l-Kütüb (Beyrut: y.y., 1407), 2: 172.

${ }^{11}$ Bkz. Mehmet Bağış, Beydâvô Tefsîri'nde Kur'ân İlimleri ve Tefsir Usûlü (Mardin: Şırnak Üniversitesi Yayınlar1, 2018), 256; Muhammed Seyyid Hüseyn ez-Zehebî, et-Tefsîr vel-müfessirûn (Kâhire, Mektebetü Vehbe, ts.), 1: 212.

${ }^{12}$ Cerrahoğlu, Tefsir Tarihi, 660; Murteza Bedir, "Nesefî Ebül-Berekât", Türkiye Diyanet Vakfı İslâm Ansiklopedisi (İstanbul: TDV Yayınları, 2006), 32: 567.

${ }^{13}$ Bkz. Zehebî, et-Tefsîr vel-müfessirûn, 1: 216; Bağdatlı İsmail Paşa, Muhammed Emîn elBâbânî, Hediyyetül-ârifin esmâül-müellifîn ve âsârül-musannifin (İstanbul: MEB Yayınları, 1951), 1: 463; Bedir, "Nesefî Ebül-Berekât", 32: 567-568; Kılıç Aslan Mavil, "Bir HanefîMâtürîdî Âlimi Ebü'1-Berekât en-Nesefî”, Uludağ Üniversitesi İlahiyat Fakültesi Dergisi 22/1 (2013): 57, 75-79. 
lan eserler arasına girmiş ve üzerlerine çok sayıda çalışma yapılmıştır. ${ }^{14}$ Nesefî'nin fikıh ve fikıh usûlü alanında yazdığı el-Müstasfâ, el-Musaffâ, el-Vâfí, el-Kâfí (Şerhu'-Vâfî), Kenzü'd-dekâik, el-Menâr, Şerhül-Müntehab fî̀ usûlil-mezheb ve Şerhu 7-Hidâye li'-Merğĝnnânî gibi eserleri, onun bu alanlardaki yetkinliğini kanıtlar niteliktedir. ${ }^{15}$

Nesefî'nin tefsir alanındaki Medâriku't-tenzîl ve hakâiku't-te'vîl adlı eseri ise i'râb ve kıraat vecihlerini içeren, belâgat inceliklerine yer veren, ehl-i sünnet akidesine göre yazılmış orta hacimli bir eserdir. ${ }^{16} \mathrm{Bu}$ eser aynı zamanda fıkıhta Hanefî mezhebinin görüş ve tercihlerine dayanak olan nassları ele alan bir dirayet tefsiridir. Ancak eserde, rivayetlere de yer verilmiş, Kur'ân' in Kur'ân'la tefsir yöntemi takip edilmiştir. ${ }^{17}$

Medârikü't-tenzîl'de ahkâm âyetlerinin tefsirine büyük önem verilmiştir. Müfessir fıkhî konuları ele alırken mezheplerin görüşlerini fazla teferruata girmeden aktarmıştır. Ancak çoğu zaman Hanefî̀ mezhebinin görüşlerini destekleyerek, diğer mezheplerin görüşlerini reddetmiştir. Bazen de Ebû Hanîfe'nin talebeleri arasında meydana gelen fikhî ihtilaflara da yer vermiştir. ${ }^{18}$

\section{BEYDÂ VÎ VE NESEFÎ'NİN AHKÂM ÂYETLERİNİ TEFSİR METOTLARINA İLISSKIIN BAZI ÖRNEKLER}

Yukarıda da temas edildiği üzere Beydâvî ve Nesefî, ahkâm âyetlerinin tefsirinde mensup oldukları mezheplerin görüşünü tercih ederek bu görüşlerin doğruluğunu çeşitli vesilelerle ispatlamaya çalışmışlardır. Dolay1sıyla hem Beydâvî hem de Nesefî'nin ahkâm âyetlerinin tefsirinde sergiledikleri metotlarını birkaç örnek üzerinde görmek yerinde olacaktır.

\subsection{Besmele'nin Fâtiha Sûresinden Olup Olmadığı Konusu}

Sûre başlarındaki Besmele'nin Kur'ân'dan bir âyet olup olmadığı konusunda, âlimler arasında ihtilaf bulunmaktadır. Besmele'yi hem Fâtiha'dan hem de diğer sûrelerden birer âyet olarak kabul eden Şâfiîler, kıraatın cehrî okunduğu namazlarda tıpkı diğer âyetlerde olduğu gibi Besmele'nin de cehrî olarak okunacağına hükmetmişlerdir. Hanefîler ise sûre başların-

${ }^{14}$ Bedir, "Nesefî Ebül-Berekât", 32: 567.

${ }^{15}$ Bk. Zehebî, et-Tefsîr ve'-müfessirûn, 1: 216.

${ }^{16}$ Bk. Kâtip Çelebi, Mustafa b. Abdullah Hâcı Halîfe, Keşfu'z-zunûn 'an esâmi'-kütüb vel-fünûn (Bağdat: Mektebetü'l-Müsennâ, 1941), 2: 1640; Zehebî, et-Tefsîr ve' l-müfessirûn, 1: 216-217.

${ }^{17}$ Demirci, Tefsir Tarihi, 176-179.

${ }^{18}$ Bk. Zehebî, et-Tefsîr vel-müfessirûn, 1: 218; Demirci, Tefsir Tarihi, 177. 
daki Besmele'yi Kur'ân'dan bir âyet olarak kabul etmedikleri için kıraatın cehrî olduğu namazlarda da Besmele'yi gizli okumuşlardır. ${ }^{19}$

Hem Beydâvî hem de Nesefî, bu konuyu kendi tefsirlerinde mezheplerin ihtilaflarıyla birlikte ele almışlardır. Beydâvî konu hakkında şöyle demektedir: "Bu konuda âlimler arasında ihtilaf vardır. Mekke ve Kûfe kıraat imâmları ve fakihleri, İbn Mübârek (ö. 181/797) ve İmâm Şâfiî (ö. 204/820), Besmele'nin Fatihâ'dan bir âyet olduğunu iddia etmişlerdir. Buna muakabil Medine, Basra ve Şâm kıraat imâmları ve fakihleri, İmâm Mâlik (ö. 179/795) ve Evzâî bunlara muhalefet etmişlerdir. İmâm Âzam Ebû Hanîfe (ö. 150/767) ise bu konuda bir şey söylememiştir. Ancak sonrakiler tarafından, Besmele'nin ona göre Fâtiha'dan olmadı̆̆ı zannedilmiştir. İmâm Muhammed b. Hasan’a (ö. 189/805) Besmele konusu sorulmuş, o da "Mushafın iki kabı arasında olanlar Allah'ın kelâmıdır." 20 demiştir.

Beydâvî, Besmele'yle ilgili yukarıdaki görüşleri aktardıktan sonra özellikle Hanefî ve Şâfiî mezhebinin görüşleri üzerinde durmuş ve kendi mezhebinin (Şâfiî) görüşünü destekleyen delilleri sıralamıştır. Beydâvî'ye göre Besmele'nin Fâtiha'dan bir âyet olduğuna delalet eden birçok hadis mevcuttur. Ebû Hureyre'den (ö. 58/678) rivayet edilen "Fâtihatül-Kitâb yedi âyettir. Bu âyetlerin ilki Bismillâhirrahmânirrahîm'dir." ${ }^{21}$ şeklindeki hadis-i şerif bunlardan birisidir. Diğer bir hadis de Ümmü Seleme'den (ö. 62/681) rivayet edilmiştir. Bu hadise göre Hz. Peygamber Fâtiha'yı okumuş ve Bismillâhirrahmânirrahîm Elhamdülillâhi Rabbilâlemîn'i bir âyet saymıştır.22

19 Ebû Saîd Nâsıruddîn Abdullâh b. Ömer el-Beydâvî, Envâru't-tenzîl ve esrâru't-te'vîll, thk. Muhammed Abdurrahmân el-Mar'aşlî (Beyrut: Dâru İhyâi't-Türâsi'l-'Arabî, 1418), 1: 25; Ebu'1-Berekât Hâfizuddîn Abdullah b. Ahmed b. Mahmûd en-Nesefî, Medârikü't-tenzîl ve hakâikü't-te'vîl, thk. Yusuf Ali el-Bedevî (Beyrut: Daru'l-Kalem, 1419/1998), 1: 25-26; Ebû Abdillâh Muhammed b. Ahmed b. Ebî Bekr el-Hazrecî el-Kurtubî, el-Câmi'u li ahkâmi'tKur'ân, thk. Ahmed el-Berdûnî, İbrâhîm Atfîş, 2. Bask1 (Kâhire: Dâru'1-Kütübi'l-Misriyye, 1384/1964), 1: 92-94.

${ }^{20}$ Beydâvî, Envâru't-tenzîl, thk. Muhammed Abdurrahmân el-Mar'aşlî, 1: 25.

${ }^{21}$ Ebû Bekir Ahmed b. Hüseyn b. Ali el-Beyhâkî, es-Sünenü's-Săğîr, thk. Abdülmu'tî Emîn Kal'acî (Pakistan: Câmi'atü'd-Dirâsâti'l-İslâmiyye, 1410/1989), "Kitâbu Fedâili'l-Kur'ân", 1: 336; Zeynüddîn Muhammed Abdurraûf el-Münâvî, Fethü's-semâvî bi tahrîci ehâdîsil-Kâdı Beydâvî, thk. Ahmed Müctebâ, (Riyad: Dâru'1-'Âsime, ts.), 1: 93; Beydâvî tefsîri'nin muhakkikleri Muhammed Subhi b. Hasan Hallâk ve Mahmud Ahmed el-Atraş, Ebû Hureyre'den gelen bu hadisin zayıf olduğunu belirtmişlerdir. Bk. Ebû Saîd Nâsiruddîn Abdullâh b. Ömer el-Beydâvî, Envâru't-tenzîl ve esrâru't-te'vîl, thk. Muhammed Subhi b. Hasan Hallâk, Mahmud Ahmed el-Atraş (Beyrut: Dâru'r-Reşî̀, 2000), 1: 8.

${ }^{22}$ Münâvî, Fethü's-semâvî, 1: 95. Beydâvî tefsîri'nin muhakkikleri Muhammed Subhi b. Hasan Hallâk ve Mahmud Ahmed el-Atraş, Ümmü Seleme'den gelen bu hadisin zayıf olduğunu belirtmişlerdir. Bk. Beydâvî, Envâru't-tenzîl, thk. Muhammed Subhi b. Hasan Hallâk, Mahmud Ahmed el-Atraş, 1: 8. 
Müfessirin öne sürdüğü bir delil de Mushaf'ın iki kapağı arasındakilerin Allah kelâmı olduğu hakkında icmânın bulunmasıdır. ${ }^{23}$

Yukarıda görüldüğü gibi Beydâvî, görüşünü desteklemek için hadisleri ve Mushaf' ın iki kapağı arasındakilerin Allah kelâmı olduğu hakkındaki icmâyı delil göstermiştir. Hafâcî (ö. 1069/1659), Inâyetül-Kâdî ve kifâyetü'rRâdî adlı Beydâvî tefsiri üzerine yazmış olduğu hâşiyesinde bu delillerle ilgili şöyle demektedir: "Bazı kimseler, Besmele'nin Fâtiha sûresinden bir âyet olduğunu kabul etmemektedir. Bazıları da 'Besmele'nin her sûrenin başında yer alan bir âyet olduğu' şeklindeki görüşü reddetmektedir. Beydâvî burada iki grubun da görüşlerini reddetmek istemiş ve birincilerin görüşüne karşılık hadisleri, ikincilerin görüşüne karşılık icmâyı delil olarak getirmiştir. Bu konuda Beydâvî’nin ileri sürdüğü bir delil de Kur'ân'dan olmayan şeylerin Kur'ân'dan soyutlanması için ulemanın aşırı titizlik göstermesidir. Bu konuda "Âmîn" kelimesinin yazılmasına dâhi izin verilmemiştir." ${ }^{24}$ Hafâcî'nin hâşiyesinde nakledildiği üzere müfessir Beydâvî, ileri sürdüğü bu son delil ile Abdullah b. Mes'ud'tan (ö. 32/65253) rivayet edilen, "Kur'ân'ı, Kur'ân'dan olmayan şeylerden soyutlayın" 25 şeklindeki hadis-i şerîf'e işaret etmiştir. Buna göre kişi, Fatihâ'dan sonra "Âmîn" kelimesini söylemekle emrolunduğu ${ }^{26}$ halde "Âmîn" kelimesi bile Mushaf'a yazılmamıştır. Şayet Mushaf'a Kur'ân'dan olmayan bir şeyin yazılmasına izin verilseydi "Âmîn" kelimesinin yazılmasına izin verilirdi. Çünkü bu kelimenin Fâtiha'dan sonra söyleneceğine dair emir vardır. Bu kelimenin yazımına izin verilmemişse başka bir şeye hayli hayli izin verilmez. ${ }^{27}$

Sonuç itibariyle Beydâvî, genel olarak konuyla ilgili bütün görüşleri verdikten sonra, Şâfîi mezhebinin görüşü olan, "Besmele'nin hem Fâtiha'dan hem de her sûreden bir âyet olduğu", görüşünü benimsemiştir. ${ }^{28}$

${ }^{23}$ Şihâbüddîn Ahmed b. Muhammed el-Hafâcî, Hâşiyetü'ş-Şihâb ale tefsîri'l-Beydâvî/Inâyetü' Kâdî ve kifâyetü'r-Râdî (Beyrut: Dâru'1-Kütübi'l-İlmiyye, 1417/1997), 1: 49; Geniş bilgi için bk. Yakup Yüksel, "Beydâvî Tefsiri'nde Besmele Tahlili”, Sakarya Üniversitesi İlahiyat Fakültesi Dergisi 14/26 (2012/2), 91-94.

${ }^{24}$ Hafâcî, Hâşiyetü'ş-Şihâb ale tefsîri't-Beydâvî, 1: 50.

${ }^{25}$ Ebû Bekir Ahmed b. Hüseyn b. Ali el-Beyhâkî, Şua'bu'l-îmân, thk. Muhammed Saîd Besyûnî, Zağlûl (Beyrut: Dâru'l-Kütübi'l-İlmiyye, 1410), 2: 547; Ebu'l-Kâsım Süleymân b. Ahmed etTaberânî, Mu'cemu'l-kebîr, thk. Hamdi b. Abdülmecîd es-Selefî, 2. Bask1 (Kâhire: Mektebetü İbn Teymiye, 1994/1415), 9: 353.

${ }^{26}$ Ebû Abdillâh Ahmed b. Hanbel, Müsnedül-İmâm Ahmed, thk. Şuayb el-Arnavûtî, 'Âdil Mürşid vd. (Beyrut: Müessesetü'r-Risâle, 1421/2001),12 : 112.

${ }^{27}$ Bkz. Hafâcî, Hâşiyetü'ş-Şihâb ale tefsîri'l-Beydâvî, 1: 50.

${ }^{28}$ Bk. Beydâvî, Envâru't-tenzîl, thk. Muhammed Subhi b. Hasan Hallâk, Mahmud Ahmed elAtraş, 1: 8. 
$\mathrm{O}$, düşüncesini ispatlamak için ilk önce konuyla ilgili delil olabilecek hadisleri vermiş, daha sonra gerek iki Mushaf kapağı arasındakilerin Allah kelâmı olduğu hakkındaki icmâyı gerekse Kur'ân'dan olmayan şeylerin Kur'ân'dan soyutlanması için aşırı titiz davranılması gerektiği hakkında âlimlerin ittifakını zikretmiş̧tir. Bundan sonra da Fatihâ'yı okuyan kimsenin "Âmîn" kelimesini söylemekle emrolunduğunu, buna rağmen Kur'ân'dan olmayan şeylerin Kur'ân'dan soyutlanması adına "Âmîn" kelimesinin Mushaf'a yazılmadığını, dolayısıyla Kur'ân'dan olmayan bir şeyin hiçbir şekilde Kur'ân'a giremeyeceğini ifade etmiştir. Neticede ise Kur'ân-1 Kerîm'de Besmele yazılmışsa, o zaman Besmele'nin Kur'ân'dan bir âyet olduğu sonucuna varmıştır. Görüldüğü üzere bu açıklamalarında da İmâm Beydâvî, kıyas delilini kullanmış olmaktadır. ${ }^{29}$

Nesefî́nin konuyla ilgili açıklamaları ise şöyledir: Medîne, Basra ve Şâm kıraat imâmları ile fakihleri, sûre başlarındaki Besmele'yi hem Fâtiha'dan hem de diğer sûrelerden bir âyet saymamışlardır. Onlara göre Besmele ancak sûrelerin arasını ayırmak ve teberrük için yazılmıştır. Bu görüş İmâm Ebû Hanîfe ile diğer Hanefî mezhep imâmlarının görüşüdür. ${ }^{30}$ Nesefî'nin bildirdiğine göre Hanefî mezhebinin delili, Ebû Hureyre'den gelen şu hadistir:

"Allah Teala, 'ben namazı (Fâtihayı) kulumla kendi aramda iki kısma ayırdım, yarısı bana ait yarısı da ona aittir. Kuluma istediği verilmiştir. Kul: 'Elhamdülillâhi Rabbi'1-âlemîn' deyince, Allah Teâlâ: 'Kulum bana hamdetti.' der. 'er-Rahmânirrahîm' deyince, Allah: 'Kulum beni methetti.' der. 'Mâliki yevmiddin' deyince, Allah: 'Kulum beni yüceltti.' der. 'İyyâkena'budü ve iyyâkenesta'în' deyince, Allah: 'Bu benimle kulum arasındadır, kuluma istediği verilmiştir' der. 'İhdine's-sırâta'l-müstakîm sırâtallezîne en'amte 'aleyhim ğayr'il-mağdûbi 'aleyhim ve le'd-dâllîn.' dediği zaman, Allah: 'Bu da kulumundur, kuluma istediği verilmiştir.' buyurmuştur." ${ }^{31}$

Nesefî̀ye göre hadiste de görüldügü üzere Fâtiha'nın ‘Elhamdülillâhi Rabbi'l-'âlemîn' âyetiyle başlaması, Besmele'nin Fâtiha'dan olmadığını

${ }^{29}$ Bk. Bağış, Beydâvî Tefsîri'nde Kur'ân İlimleri, 258-261.

${ }^{30}$ Nesefî, Medârikü't-tenzîl, 1: 25-26.

${ }^{31}$ Ebu'-Hasen Müslim b. Haccâc el-Kuşeyrî, Sahîhu Müslim, thk. Muhammed Fuâd Abdülbâkî (Beyrut: Dâru İhyâi't-Türâsi'l-'Arabî, ts.), "Salât", 395; Ebû Bekir Ahmed b. Hüseyn b. Ali elBeyhâkî, Sünenül-kübrâ, thk. Muhammed Abdülkâdir 'Ata (Beyrut: Dâru'-Kütübi'l-İlmiyye, 1424/2003),2 : 58; Nesefî, Medârikü't-tenzîl, 1: 26. 
göstermektedir. Netice itibariyle Besmele Fâtiha'dan bir âyet değilse diğer sûre başlarında hayli hayli değildir. ${ }^{32}$

Beydâvî tefsîri muhakkikleri Muhammed Subhî Hallâk ile Mahmud Ahmed el-Atraş'a göre de Besmele, muhakkak surette fâsıla (sûrelerin arasinı ayırmak) ve teberrük için inmiştir. Buna İbn-i Abbâs'ın rivayet ettiği

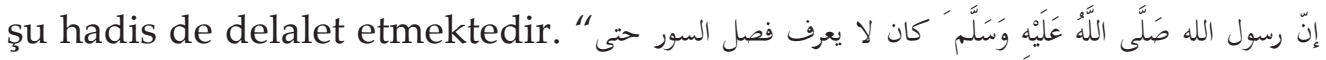
Hz. Peygamber, kendisine Besmele ininceye kadar sûrelerin bitiş yerini bilmezdi." ${ }^{33}$ Ancak bu konuda yukarıda da geçtiği üzere âlimler arasında ittifak yoktur. Her bir grubun da kendine göre delilleri vardır. Fakat âlimler Besmele'nin, Neml sûresi 30. âyetin bir kısmı olduğu konusunda kesinlikle ittifak etmişlerdir. ${ }^{34}$

\subsection{Kasr-1 Salat}

Şâfiî ve Hanefî mezhepleri arasında ihtilaflı konulardan birisi de kasr-1 salât'tır. Bu konu hem Beydâvî hem de Nesefî tefsirlerinde tafsilatlı olarak ele alınmıştır.

Kasr-1 salât, dört rekâtlı namazların ikiye kısaltılması, yani iki rekât olarak kılınması anlamına gelir. ${ }^{35}$ Yüce Allâh, Kur'ân'da namazların kısal-

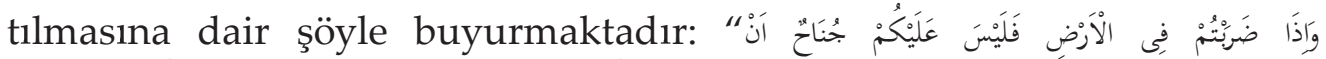
Yeryüzünde sefere çıktığınız vakit kâfirlerin size saldırmasından korkarsanız, namazı kısaltmanızdan ötürü size bir günah yoktur. Şüphesiz kâfirler sizin apaçık düşmanınızdır." (en-Nisâ 4/101).

Yukarıdaki âyette namazı kısaltmak, düşmanlardan korkulması şartına bağlanmıştır. Ayetin siyâk sibâkına bakıldığında ise bir önceki âyette Allah yolunda hicret edenlerin durumundan ${ }^{36}$, bir sonraki âyette de savaş durumunda namazın nasıl kılınacağından bahsedilmektedir. ${ }^{37}$ Âyetin mefhumu her ne kadar savaş vb. olağanüstü durumlarla ilgili olup, sıradan

32 Nesefî, Medârikü't-tenzîl, 1: 26.

${ }^{33}$ Muhammed Ali es-Sâbûnî, Ravâiu '-beyân tefsîru âyâti'l-ahkâm, 3. Bask1 (Dimeşk: Mektebetü'lĞazâlî, 1400/1980), 1: 52; Ahmed en-Nükerî, Câmiu'l'ulûm fì ıstılahâti'-fünûn, thk. Hasan Hânî Fahs (Beyrut: Dâru'l-Kütübi'l'İlmiyye, 2000), 1: 166.

${ }^{34}$ Bk. Beydâvî, Envâru't-tenzîl, thk. Muhammed Subhi b. Hasan Hallâk, Mahmud Ahmed elAtraş, 1: 8 .

${ }^{35}$ Muhammed Naîm Muhammed Hânî Sâ'î, Mevsu'atü mesâili'l-cumhûr, fil-fikhil-İslâm, 2. Baskı (Misır: Dâru's-Selâm, 1428/2007), 1: 210; Zekiyüddin Şâban, İslâm Hukuk İlminin Esasları, çev. İbrahim Kâfi Dönmez (Ankara: Türkiye Diyanet Vakfı Yayınları, 2018), 258; Mehmet Erdoğan, Fikıh ve Hukuk Terimleri Sözlüğü (İstanbul: Ensar Neşriyat, 2016), 294.

36 en-Nisâ $4 / 100$.

37 en-Nisâ 4/102. 
yolculuklara ilişkin olmasa da öteden beri seferîlik konusundaki hükümler, bu âyetle irtibatlı olarak ele alınmıştır. ${ }^{38}$ Zira sıradan yolculuklarda Hz. Peygamber'in namazları kısalttığına dair rivayetlerin çokluğu, böyle bir yolun tercih edilmesine imkân sağlamaktadır.

Cumhur ulemâ, seferde (yolculukta) korku olsun veya olmasin, namazların kısaltılabileceği konusunda hem fikirdir. Ancak büyük çoğunluk, hem kasr (kısaltma) hem de itmâmı (tam kılma) caiz görüyorken, İmâm Ebû Hanife ve bir kısım âlimler, yolculukta namazları kısaltmanın vacip olduğunu iddia etmektedirler. ${ }^{39}$ Ebû Hanîfe'ye göre bir kişi, yolculukta iki rekât kıldıktan sonra teşehhüt miktarı oturur ve ardından iki rekât daha kılarsa yani namazını kısaltmazsa, namazı sahih olur, ancak son iki rekât nafile olur. ${ }^{40}$

Beydâvî bu konuda şöyle demiştir: “Âyette, 'namazı kısaltmanızdan ötürü size bir günah yoktur' gibi bir ifadenin olması, kısaltmanın caiz olduğuna delâlet eder. Ona göre âyetin manasından, kısaltmanın vacip olduğu anlaşılmamaktadır. Nitekim Hz. Peygamber'in namazları seferde tam kılması ve Hz. Aişe'nin Umre'de Rasûlullah (s.a.s) ile beraberken, "Yâ Rasûlallah! Namazları bazen kısalttım bazen tam kıldım, bazen oruç tuttum bazen de tutmadım" demesi ve Rasûlullah'ın (s.a.s) da ona, "İyi yaptın yâ Aişe!"41 diyerek tasdik etmesi, bu görüşü destekler mahiyettedir. İmâm Ebû Hanife ise Hz. Ömer'in (ö. 23/644) hadisi ile Hz. Aişe'den (ö. 58/678) rivayet edilen diğer bir hadisi delil getirerek, seferde namazları kısaltmanın vacip olduğunu söylemiştir. Bu hadislerden birincisine göre "Hz. Ömer (r.a) şöyle demiştir: 'Peygamberinizin bildirmesine göre sefer namazı, kısaltma olmaksızın, tam olarak iki rekâttır." 42 İkinci hadiste ise Hz. Aişe şöyle demiştir: 'Namaz en başta, ikişer rekât olarak farz kulındı. Seferde olduğu gibi bırakıldı. Hadarda (ikamet edilen yerde) ise arttırıldr." ${ }^{43}$ Beydâvî̀ye göre bu iki hadis, sahih olsa bile zahiren âyetin manasına muhaliftir. Dolayısıyla te'vil edilmeleri icap eder. Birinci hadiste aslında iki rekâtın, sıhhat ve kifâyet (yeterlilik) bakımından dört rekât gibi tam olduğu kastedilmiştir. Yani seferde ruhsattan istifâde

${ }^{38}$ Bk. Komisyon, İman ve İbadetler /İlmihal (Ankara: DİB Yayınları, 2006), 1: 327.

${ }^{39}$ Bk. Sâbûnî, Ravâiul-beyân, 1: 515; Muhammed Naîm, Mevsu'atü mesâili'l-cumhûr, fi'l-fikhilİslâm, 1: 210; Komisyon, İman ve İbadetler/İlmihâl, 1: 327.

${ }^{40}$ Muhammed Naîm, Mevsu'atü mesâilil-cumhûr fil-fikhil-İslâm, 1: 210; Komisyon, İman ve İbadetler/İlmihâl, 1: 327.

${ }^{41}$ Beyhâkî, Sünenül-kübrâ, 3: 142; Ebu'l-Hasen Ali b. Ömer ed-Dârekutnî, Sünenü'd-Dârekutn̂̂, thk. Seyyid Abdullâh Hâşim (Beyrut: Dâru'l-Ma'rife, 1966/1386), "Sıyâm", 4.

${ }^{42}$ Ebû Bekir Abdullâh b. Muhammed b. Ebî Şeybe, Kitâbül-Musannef fil-ehâdîs ve'l-âsâr, thk. Kemâl Yûsuf el-Hût (Riyad: Mektebetü'r-Rüşd, 1409), 2: 203.

${ }^{43}$ Münâvî, Fethü's-semâvî, 2: 521. 
ederek iki kılan kişi, tam kılmış gibi sayılır. İkinci hadis de seferde arttırmanın (dört rekât olarak kılmanın) câiz oluşuna engel değildir. Dolayısıyla bu meselede âyeti te'vil etmeye gerek yoktur. ${ }^{44}$

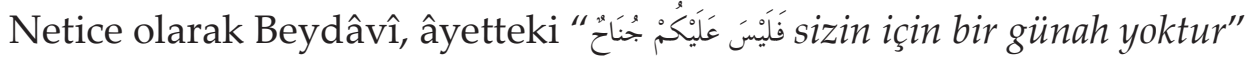
ifadesi üzerinde yoğunlaşmış, Hz. Ömer ile Hz. Aişe'den rivayet edilen hadisleri de bu minvalde ve Şâfiî mezhebinin görüşüne göre te'vil etmiştir. ${ }^{45}$

Nesefî ise bu âyetin tefsirinde Hanefî mezhebinin görüşünü tercih ederek bu görüşün doğruluğunu Hz. Ömer' in "Peygamberinizin bildirmesine göre sefer namazı, kısaltma olmaksızın, tam olarak iki rekâttır." ${ }^{46}$ şeklindeki hadisiyle ispatlamaya çalışmıştır. Ona göre hadiste, sefer namazının özü

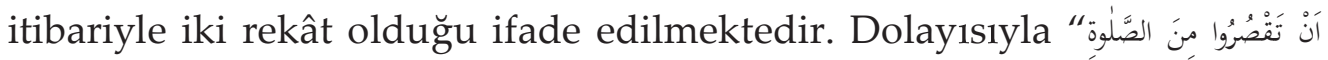
namazı kısaltmanız" ifadesinden hakikî anlamda bir kısaltma anlaşılmamalıdır. Çünkü sahabîler, namazı dört rekât olarak kılmaya alıştıkları için seferde özü itibariyle iki rekât olarak kılınan namazı, kısaltılmış ya da noksan bırakılmış olarak algıladılar. Bu sebeple onların bu düşüncesine binâen âyet-i kerimede seferdeki namaz hakkında "kısaltma" ifadesi kullanılmış ve bu şekilde kıldıklarında onlar için bir günah olmayacağı beyan edilmiştir. Nesefî́nin konu hakkında aktardığı diğer bir hadiste de Ya'lâ b. Ümeyye (ö. 60/679-80 [?]), Hz. Ömer'e şöyle demiştir: “Biz güvende olduğumuz halde namazlarn niçin kısaltıyoruz? Hz. Ömer de ona "Vallahi bir seferinde şu an senin şaşırdığın gibi şaşırmış ve Rasûlullâh'a aynı soruyu sormuştum. O da 'Bu (kısaltma) Allah'ın (c.c) size verdiği bir sadakadır. Onun sadakasın kabul edin.' diye buyurmuştur. Nesefî'ye göre bu iki rivayetten, seferde kılınan namazın ikmâlinin (tam kılınmasının) caiz olmadığı, kısaltılmasının ise azimet olduğu anlaşılmaktadır. Çünkü hadiste de ifade edildiği üzere tasaddukta bulunan Zât, kendisine itaat edilmesi gereken Allah Teâlâ olup, böyle bir sadakanın reddedilmesi ihtimal dahilinde değildir. ${ }^{47}$

${ }^{44}$ Beydâvî, Envâru't-tenzîl, thk. Muhammed Abdurrahmân el-Mar'aşlî, 2: 93; Bk. Bağı̧, Beydâvî Tefsîri'nde Kur'ân İlimleri, 264-266.

${ }^{45}$ Bk. Bağış, Beydâvî Tefsîri'nde Kur'ân İlimleri, 264-266.

46 İbn Ebî Şeybe, Kitâbü'l-Musannef, 2: 203.

${ }^{47}$ Bk. Nesefî, Medârikü't-tenzîl, 1: 390. Bu konuda Hanbeli mezhebi ise tıpkı Şâfiîler gibi seferde namazı kısaltmanın ruhsat olduğu görüşündedir. Onlara göre seferde namaz kılan kişi ister iki isterse dört rekât kılabilir. Mâlikî mezhebine göre de seferde namazı kısaltmak sünnettir, vacib değildir. Ancak İmâm Mâlik ruhsata uyularak namazın kısaltılmasını, tam kılınmasından evlâ görmektedir. Ona göre birisi seferde namazı dört rekât olarak kılarsa ve namazın vakti hâlâ çıkmamışsa namazını iki rekât olarak iade etmek zorundadır. Bk. Kurtubî, el-Câmi'u li ahkâmil-Kur'ân, 5: 351-352; Sâbûnî, Ravâiu l-beyân, 1: 515. 


\subsection{Nikâh Akdinde (Sözleşmesinde) Velî Şartı}

Velâyet, bir başkası üzerinde geçerli olan bağlayıcı söz ve karar alma yetkisidir. Velâyet hakkına sahip olan kimseye de velî denir. Kadın veya çocuğun velisi gibi... ${ }^{48}$ Evlenme konusundaki velâyet, özel (velâyet-i hâsse) ve genel (velâyet-i âmme) olmak üzere ikiye ayrılır. Özel velâyet, kadının erkek yakınlarına tanınan yetkidir. Genel velâyet ise bu konuda kamu otoritesine sahip kişiye tanınan yetkidir. ${ }^{49}$

Âlimler nikâhın sahih olması için velâyetin şart olup olmadığı konusunda görüş ayrılığına düşmüşlerdir. İmâm Mâlik ve İmâm Şâfiî̀ye göre nikâh ancak velînin izni ile geçerli olur. Dolayısıyla nikâhın sahih olabilmesi için velâyet şarttır. Ebû Hanîfe, Züfer (ö. 158/775), Şa'bî (ö. 104/722) ve Zührîye (ö. 124/742) göre ise bir kadın, velî olmaksızın dengi olan bir erkekle nikâh kıyarsa o nikâh caizdir. Dâvud ez-Zâhirî (ö. 270/884), bu konuda bakire ile dul kadının arasını ayırmıştır. Ona göre bakirenin nikâhında velî şart iken dul kadının nikâhında şart değildir. Bu konuda İmâm Mâlik'in görüşüyle ilgili gelen diğer bir rivayete göre ise o, kadının nikâhındaki velâyeti farz değil, sünnet olarak değerlendirmektedir. Bu durumda velâyet ona göre nikâhın sahih olmasının şartı değil, nikâhı tamamlayan unsurlardandir. ${ }^{50}$

Hanefî mezhebine göre kadının akıllı ve hür olması, ergenlik yaşına gelmesi ve rızasının bulunması gibi şartlar yerine geldiğinde, nikâhı sahih olur. Kadın ister dul isterse bekar olsun nikâhta velinin iznine ihtiyaç yoktur. Şâfiîlerin de içinde bulunduğu cumhur'a göre ise bu şartlara ilave olarak velinin izni de gerekmektedir. ${ }^{51}$

Beydâvî ve Nesefî de velâyet konusuyla ilgili âyetlerin tefsirinde, mensup oldukları mezheplerinin görüşleri yönünde tercihte bulunmuşlardır. Mezhepler nikâh akdinde kadın için velinin gerekli olup olmadığ 1 konusunda delil olarak şu âyetler üzerinde durmaktadırlar:

${ }^{48}$ Bk. Şemsü'1-Eimme Muhammed b. Ahmed b. ebî Süheyl es-Serahsî, el-Mebsût (Beyrut: Dâru'1M'arife, 1414/1993), 16: 124; Muhammed b. Ali et-Tehânevî, Mevsûatü keşşâfi ıstılâhatil-fünûn ve'-'ulûm, thk. Ali Dahrûc (Beyrut: Mektebetü Lübnân Nâşirûn, 1996,) 2: 1806; Bk. Abdülaziz Bayındır, "Fıkha Göre Nikâh Sözleşmesinde Velinin Yeri", İstanbul Üniversitesi IIlahiyat Fakültesi Dergisi 4 (2002): 46; Erdoğan, Fikıh ve Hukuk Terimleri Sözlü̆̆̈̈, 602-603.

${ }_{49}$ Bayındır, "Fıkha Göre Nikâh Sözleşmesinde Velinin Yeri”, 46; Erdoğan, Fikıh ve Hukuk Terimleri Sözlü̈̆̈̈, 602.

${ }^{50}$ Ebu'l-Velîd, Muhammed b. Ahmed b. Muhammed b. Ahmed el-Kurtubî İbn Rüşd, Bidâyetü'l-müctehid ve nihâyetül-muktesıd (Kâhire: Dâru'l-Hadîs, 2004),3 : 36; Ebû Abdillâh Muhammed b. İdrîs b. Abbâs b. Osmân b. Şâf'i eş-Şâfiî, el-Ümm (Beyrut: Dâru'l-Ma'rife, 1990), 5: 13; Kurtubî, el-Câmi'u li ahkâmi'-Kur'ân, 3: 158-159.

${ }^{51}$ Burhânüddîn Ali b. Ebibekr b. Abdilcelîl el-Ferğânî el-Merğînânî, el-Hidâye fi ş̧erhi Bidâyeti'mübtedî, thk. Talâl Yûsuf (Beyrut: Dâru İhyâi't-Türâsi'l-Arabî, ts.), 1: 191. 


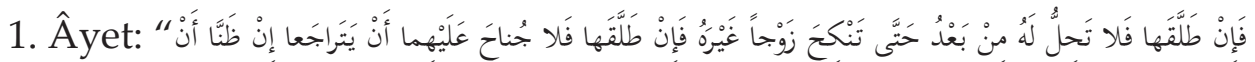
Eğer erkek karısını (üçüncü defa) boşarsa, kadın, onun dışında başka bir kocayla nikâhlanmadıkça ona helâl olmaz. (Bu koca da) onu boşadığı takdirde, onlar (kadın ile ilk kocası) Allah'ın koyduğu ölçüleri gözetebileceklerine inanıyorlarsa tekrar birbirlerine dönüp evlenmelerinde bir günah yoktur. İşte bunlar Allah'ın, anlayan bir toplum için açıkladığı ölçüleridir." (el-Bakara 2/230).

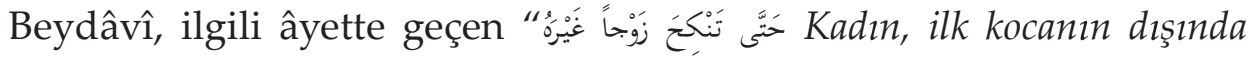
başka biriyle nikâhlanmadıkça..." ifadesinin tefsirinde, nikâhın da tıpkı evlilik gibi hem erkeğe hem de kadına isnat edildiğini söylemiş ancak kadının, velinin izni olmadan kendi nikâhını kıyıp kıyamayacağı konusuna değinmemiştir. ${ }^{52}$

Nesefî̀ye göre ise âyetin söz konusu ifadesinde geçtiği üzere nikâh akdi, tıpkı erkekte olduğu gibi kadına da isnat edilmiştir. Zira nikâh, bizzat evlilik gibi iki taraflı bir durumdur. Dolayısıyla burada nikâh akdinin hem erkek hem kadın, ikisinin ibaresiyle geçerli olacağına delil vardır. ${ }^{53}$ Netice itibariyle Nesefî bu âyetten hareketle kadını, nikâhın iki tarafından biri olarak görmekte ve kendi nikâhını kıyabilme yetkisinin bulunduğunu iddia etmektedir.

Bir bütün olarak âyetin manasına bakıldığında ise burada, kadının velisiz olarak kendi nikâhını kıyması ile ilgili durumdan daha çok, kocası tarafından üç talakla boşanmış bir kadının kocasına tekrar dönmek istemesi durumunda, ikinci bir koca ile evlenmesi gerektiğinden bahsedilmektedir. Zira âyetin sebeb-i nüzulü de buna işaret etmektedir. ${ }^{54}$ Dolayısıyla âyet-i kerîme, Hanefî mezhebinin ilgili görüşünü desteklemesi bakımından sarih ve net bir delil olarak değerlendirilmemektedir.

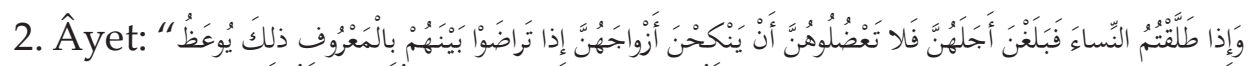

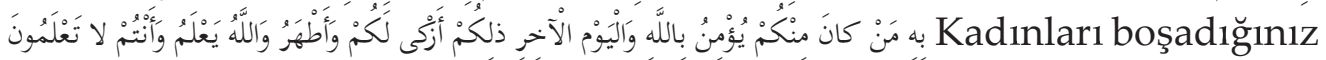
ve onlar da bekleme sürelerini bitirdikleri zaman kendi aralarında aklın ve dinin gereklerine uygun olarak güzellikle anlaştıkları takdirde, eşleriyle

${ }^{52}$ Beydâvî, Envâru't-tenzîl, thk. Muhammed Abdurrahmân el-Mar'aşlî, 1: 142.

${ }^{53}$ Nesefî, Medârikü't-tenzîl, 1: 192.

54 “Rifâ'e adlı sahabînin eşi Hz. Peygamber'e gelerek, 'Rifâ‘e beni boşadı, daha sonra Abdurrahman b. Zübeyr benimle evlendi. Yalnız Abdurrahman'daki, elbise püskülü gibidir' Hz. Peygamber de 'Sen Rifâ'e'ye dönmek mi istiyorsun? diye sordu. Kadın, 'evet' dedi. Bunun üzerine Hz. Peygamber, 'Sen onun (Abdurrahman'ın) balcı̆̆ını, o da senin balc1ğını tatmadıkça, ona (Rifâ'e'ye) dönemezsin' buyurdu." Bk. Müslim, "Nikâh", 1433; Muhammed b. İsa et-Tirmizî, Sünenü't-Tirmizî, thk. Ahmed Muhammed Şâkir, Muhammed Fuad Abdülbâkî, İbrahim 'Utva, 2. Baskı (Mısır: Mektebetü ve Matbaatu Mustafa el-Bâbî, 1395/1975), “Nikâh”, 26. 
(yeniden) evlenmelerine engel olmayın. Bununla içinizden Allah'a ve ahiret gününe iman edenlere öğüt verilmektedir. Bu, sizin için daha hayırlı ve daha temizdir. Allah bilir, siz bilmezsiniz." (el-Bakara 2/232).

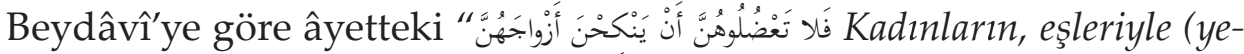
niden) evlenmelerine engel olmayın!" ifadesinde geçen muhataplar, velilerdir. Çünkü âyet-i kerîme, Ma'kil b. Yesâr'ın, kız kardeşini eski kocasına dönmekten alıkoymaya çalışması üzerine inmiştir. ${ }^{55} \mathrm{Bu}$ da kadının kendi nikâhını kıyamayacağının delilidir. Şayet kadın, kendi nikâhını kıyabilme yetkisine sahip olsaydı, velilere yapılan (Ma'kil b. Yesâr (ö. 59/679 [?]) ve onun durumunda olan herkes) yapilan "Evlenmelerine engel olmayın." şeklindeki hitabın anlamı olmazdı. Âyetin söz konusu ifadesinde nikâh akdinin kadınlara isnat edilmesinde de bir çelişki bulunmamaktadır. Çünkü neticede nikâh akdi kadınların iznine dayanmaktadır. ${ }^{56}$

Dikkat edilirse Beydâvî, her ne kadar kadının kendi nikâhını kıyabilme yetkisinin bulunmadığını ve bu konuda velisinin izninin gerekli olduğunu söylese de nihayetinde yapılacak evlilikte kadının rızasının bulunması gerektiğini de vurgulamıştır.

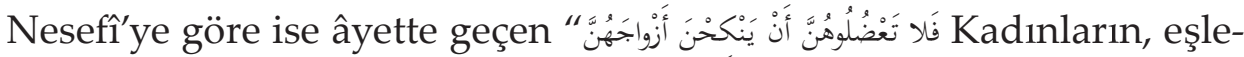
riyle (yeniden) evlenmelerine engel olmayın!" şeklindeki ifadede, nikâh akdinin geçerli olmasının, kadınların ifadesine bağlı olduğuna işaret vardir. Bu ifadedeki muhataplar ise ya iddeti biten eşlerinin evlenmesini engelleyen kocalar ya ric'î talakla boşanmış kadınları, kocalarına dönmekten alıkoyan veliler ya da genel olarak bütün insanlard $1 .{ }^{57}$ Çünkü bu durumdaki kimselerin karşılıklı rıza ile evlenmelerine eski kocalar ve velilerin yanı sıra başka kimseler de engel olmaya çalışabilir. ${ }^{58}$

Nikâh kelimesi "evlilik için yapılan akit" anlamında olduğu gibi bizzat "evlilik" (tezevvüc) ya da "cinsel ilişki" anlamlarına da gelmektedir. ${ }^{59}$ Nite-

${ }^{55}$ Ayetin sebebi nüzulü ile ilgili rivayete göre Ma'kil b. Yesâr'ın kız kardeşi, Ebu'd-Dehdâh adında bir sahâbî ile evliydi. Ebu'd-Dehdâh onu ric'î talakla boşamıştı. İddeti bitince de hem Ebu'd-Dehdâh hem de eşi birbirlerine dönmek (yeniden evlenmek) istemişler. Kadının abisi Ma'kil b. Yesâr'ın bu evliliğe karşı çıkması üzerine yukarıdaki ayet (el-Bakara, 2/232) inmiş ve Ma'kil de bu evliliğe razı olmuştur. Bk. Şâfiî, el-Ümm, 5: 13; Ebû Abdillâh Muhammed b. İsmâil el-Buhârî, el-Câmi'ü's-sahîh el-muhtasar, thk. Mustafa Dîb el-Buğâ (Beyrut: Dâru ibn Kesîr- Yemâme, 1407/1987), "Tefâsîr", 2.

${ }^{56}$ Beydâvî, Envâru't-tenzîl, thk. Muhammed Abdurrahmân el-Mar'aşlî, 1: 145.

${ }^{57}$ Nesefî, Medârikü't-tenzîl, 1: 93.

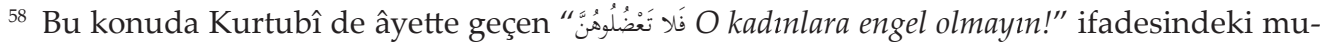
hatap kimselerin, âyetin sebeb-i nüzul rivayetinden hareketle, "veliler" olduğunu ifade etmiştir. Bk. Kurtubî, el-Câmi'u li ahkâmi '-Kur'ân, 3: 158.

${ }^{59}$ Ebu'l-Fadl Cemâlüddîn Muhammed b. Mukrim b. Ali İbn Manzûr, Lisânu'-Arab (Beyrut: Dâr Sâdır, 1414/1993), 2: 625. 


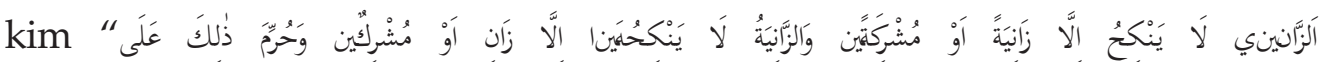
الْمُوْمنِنينَ Zina eden erkek ancak zinakâr veya müşrik bir kadınla evlenir, zina eden kadınla da ancak zinakâr veya müşrik bir erkek evlenir. Bu müminlere haram kılınmıştır." (en-Nûr 24/3) âyetinde de bizzat evlilik manasında kullanılmıştır. Aynı şekilde yukarıdaki (Bakara 2/232) âyette de "nikâh" kelimesi, akit anlamından daha çok "evlilik hayatı kurma" ya da "eski kocalarıla ye-

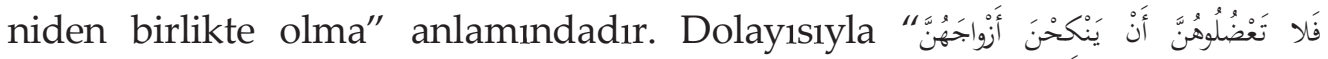
Kadınların, eşleriyle (yeniden) evlenmelerine engel olmayın!" ifadesinde teorikte yapılacak evlilik sözleşmesinden ziyade, pratikte meydana gelecek evlilik hayatından bahsedilmektedir. Neticede Hanefîlerin ileri sürdüğ̈ü "nikâh akdinin geçerli olmasının, kadınların ifadesine bağlı olduğu" şeklindeki görüş, âyetin söz konusu ifadesinden zımnen anlaşılsa da bir bütün olarak âyette asıl vurgulanmak istenen durum, muhtemelen meşru ölçüler çerçevesinde evlilik hayatı kurmak isteyen bir kadına, velilerin engel olmamaları gerektiği şeklindedir.

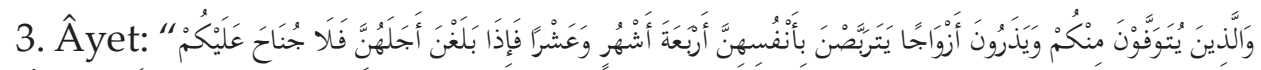

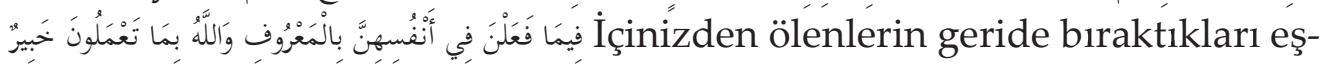
léri, kendi kendilerine dört ay on gün (iddet) beklerler. Sürelerini bitirince artık kendileri için meşru olanı yapmalarında size bir günah yoktur. Allah, yaptıklarınızdan hakkıyla haberdardır." (el-Bakara 2/234).

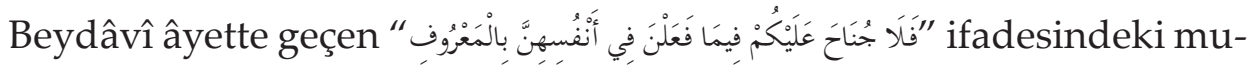
hatapların yöneticiler ve genel olarak tüm müslümanlar olduğunu ifade etmiştir. Ona göre bu ifadenin anlamı, kadınların şeriat sınırları içerisinde evliliğe dair (gelen talepleri değerlendirme vb.) yaptıkları eylemlerde yöneticilere veya diğer müslümanlara bir günah olmadı̆̆ı, şeklindedir. Bunun mefhûm-1 muhalifi ise şudur: Kadınlar, şeriatın izin verdiği maruf sınırların dışına çıkarlarsa, yöneticiler ile diğer bütün müslümanların onları engellemesi gerekir. Yoksa onlar için bir günah söz konusu olur. ${ }^{60}$

Görüldüğü üzere Beydâvî, bu âyette de kadınların evlenme konusunda tek başlarına bir yetkilerinin olmadığını, bu konuda devlet yöneticileri ile yetkili diğer müslümanların da söz sahibi olduklarını söylemektedir.

Nesefî ise âyetin bu ifadelerinde geçen muhatapların devlet yöneticileri ve hakimler olduğunu ifade etmiş, ancak mefhûm-1 muhalifine değinmemiştir. ${ }^{61}$ Dolayısıyla onun da bu âyeti kendi mezhebinin görüşü doğrultusunda yorumladı̆̆ını söyleyebiliriz.

${ }^{60}$ Beydâvî, Envâru't-tenzîl, thk. Muhammed Abdurrahmân el-Mar'aşlî, 1: 145.

${ }^{61}$ Nesefî, Medârikü't-tenzîl, 1: 196. 
Burada dikkat çeken bir nokta da şudur ki Beydâvî, Şâfiî mezhebinde hüccet değeri olan mefhûm-1 muhâlefet kuralını ${ }^{62}$ işleterek âyeti yorumlamiş, Nesefî ise bu kurala temas etmemiştir.

Malum olduğu üzere mefhûm-1 muhâlefet kuralı, insanlar arası konuşmalarda ve yazılarda muteber olsa bile bu kuralın şer'î hükümler hususunda delil olup olmayacağı konusu tartışmalıdır. Hanefîlere göre mefhûm-1 muhâlefet, sahih bir delil getirme yolu değildir. Bununla şer'î hüküm sabit olmaz. Yani mefhûm-1 muhâlif, hüccet sayılmayıp onunla amel edilmez. Şâfiîlere göre ise sahih bir delil getirme yoludur ve bununla şerî̀ hüküm sabit olur. Dolayısıyla mefhûm-1 muhâlif, hüccet olup onunla amel edilir. ${ }^{63}$

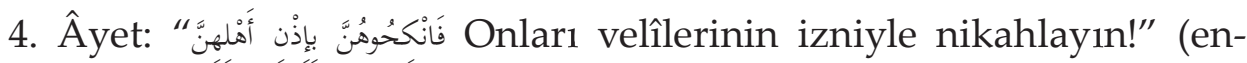
Nisâ, 4/25).

Nesefí̀ye göre Nisâ sûresi 25. âyette geçen yukarıdaki ifadelerde, nikâhta velinin izninin alınması gerektiği ancak son sözün, yani nikâh akdinin ancak kadının ibaresi ile gerçekleşeceği belirtilmektedir. Nesefî' âyetteki bu ifade için "Bu bizim için delildir." demek suretiyle bu konuda kendi mezhebi (Hanefî) ile aynı görüşte olduğunu belirtmiş olmaktadır. ${ }^{64}$ Beydâvî'ye göre ise âyetin bu ifadesinde mutlak olarak velilerin izninden bahsedilmektedir. Buradan, Hanefîlerin anladığı gibi "velinin sadece izni alınır, nikâh akdi kadının ifadesiyle gerçekleşir" şeklindeki bir anlam çıkmamaktadır. ${ }^{65}$

\subsection{Kurû' Meselesi}

Hanefî ve Şâfiî mezhepleri arasında tartışlagelen bir diğer konu da

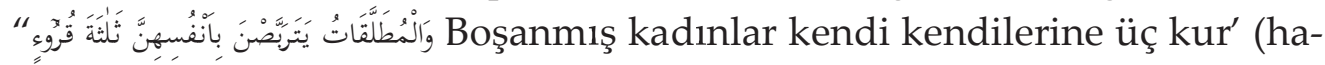
yız veya tuhr müddeti) beklerler." (el-Bakara 2/228) âyetinde geçen $k u r^{\prime}$ lafzının ihtiva ettiği anlam ile ilgilidir.

القُرُْ hem ötreli $k u r^{\prime}$ şeklinde hem de üstünlü kar' şeklinde, hayız (kadınların adet dönemi) ve tuhr (kadınların temizlik dönemi) anlamlarına gelmektedir. Bu kelime "vakit" anlamında da kullanılır. Zira hem tuhr hem de hayız, bir vaktin içinde meydana gelmektedir. Kelimenin cemisi (çoğulu) ise

\footnotetext{
${ }^{62}$ Meskût birakılan (hakkında susulmuş/konuşulmamış) şeyin hükmünün, mantûk olanın (beyan edilen sözün) hükmüne nefy ve isbât cihetiyle (olumlu veya olumsuz anlamda) muhalif olmasıdır. Komisyon, Türk Hukuk Lûgatı (Ankara: Başbakanlık Basımevi, 1998), 223; Şâban, İslâm Hukuk İlminin Esasları, 527.

63 Şâban, İslâm Hukuk İlminin Esasları, 532-533; Molla Hüsrev, Mirkâtü'l-vüsûl Tercümesi ve Şerhi, trc. Haydar Sadıkoğlu (İstanbul: Özgü Yayıncılık, 2014), 242-243.

${ }^{64}$ Nesefî, Medârikü't-tenzîl, 1: 349.

65 Beydâvî, Envâru't-tenzîl, thk. Muhammed Abdurrahmân el-Mar'aşlî, 2: 69.
} 


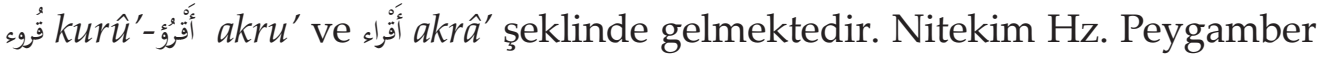
bَ طَعي الصلاةَ" أَيامَ أَقَرَائك Hayız vakitlerinde namazı terket!”66 diye buyurmuştur. Bu kelime cem' (toplama) manasında da kullanılmaktadır. Dolayısıyla kar' kanın rahimde toplanması anlamına gelir. Bu da ancak tuhr döneminde vâki olur. ${ }^{67}$

Rivayete göre Abdullâh b. Ömer hayız döneminde olan eşini boşamış, babası Hz. Ömer de bu konuda Allah Rasûlünden fetva istemişti. Rasûlullâh da: “Ona söyle eşine dönsün ve eşi tuhr dönemine girdiğinde (temizlendiğinde) isterse onu boşasın. İşte kadınların talâkı (boşanması) ile ilgili Allah Teâlâ'nın emrettiği iddet bu şekildedir." demiştir. ${ }^{68}$

İbn Ömer (ö. 73/692), Hz. Aişe (ö. 58/678), Zeyd b. Sâbit (ö. 45/665 [?]) (r.a), İmâm Şâfiî, İmâm Mâlik ve Hicaz ehline göre kur' yukarıdaki hadisin de delaletiyle, tuhr anlamina gelir. Hz. Ali, Hz. Ömer, İbn Mes'ûd, Ebû Mûsa el-Eş'arî (ö. 42/662-63), (r.a) Ebû Hanîfe ve Irak ehline göre ise kur', hayız anlamındadır. Delilleri de "دَعي الصلاةَ أَيامَ أَقَرَائكِ Hayı dönemlerinde namazı terket!" şeklindeki hadistir. Bu konuda Kisâî, Ferrâ ve Ahfeş de aynı görüştedir. Netice itibariyle $k u r^{\prime}$ kelimesi ezdadtandir. Hem tuhr hem de hayız anlamina gelir. ${ }^{69}$

Söz konusu âyetin tefsiriyle ilgili Beydâvî'nin Envâru't-Tenzîl'ine bakıldığında Beydâvî, bu konuda Şâfiî mezhebinin görüşünü tercih ederek kuru' kelimesinin tuhr dönemleri anlamına geldiğini söylemektedir. Onun bu konudaki delilleri şöyledir: ${ }^{70}$

1. Rahim, tuhr döneminde temiz olur. Zira meşru ve sünnete uygun boşama, hayız döneminde değil, tuhr döneminde gerçekleşmelidir. ${ }^{71} \mathrm{Ni}$ -

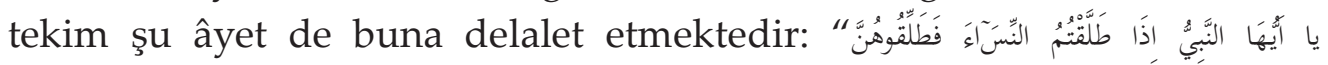
لع لعَّنَهنَّ Ey peygamber! Kadınları boşamak istediğinizde, onları iddetlerini dikkate alarak (tuhr döneminde) boşayın." (et-Talâk 65/1).

2. Hanefîlerin ileri sürdüğ̈ü "طلاق الأمة تطليقتان وعدتها حيضتان Cariyenin talakı

${ }^{66}$ Dârekutnî, Sünenü'd-Dârekutnî, "Hayz", 1.

${ }^{67}$ Bk. İbn Manzûr, Lisânu'l-Arab, 1: 130-131; Ebu'1-Kâsım el-Huseyn b. Muhammed Râğ 1 b el-Isfahânî, el-Müfredât fî garîbi'l-Kur'ân, thk. Safvân Adnân ed-Dâvudî (Dimeşk; Beyrut: Dâru'l-Kalem; Dâru'ş-Şâmiyye, 1412/1992), 688.

${ }^{68}$ Buhârî, "Talâk", 1; Beyhâkî, Sünenül-kübrâ, 5: 323; Dârekutnî, Sünenü'd-Dârekutnî, "Talâk", 1.

69 Bk. İbn Manzûr, Lisânu' 7-Arab, 1: 131; İbn Rüşd, Bidâyetül-müctehid, 3: 108-109.

70 Beydâvî, Envâru't-tenzîl, thk. Muhammed Abdurrahmân el-Mar'aşlî, 1: 141.

${ }^{11}$ Buhârî, "Talâk", 1; Ebû Bekr Cessâs Ahmed b. Ali er-Râzî, Ahkâmu'l-Kur'ân, thk. Muhammed Sâdik el-Kamhâvî (Beyrut: Dâru İhyâi't-Türâsi'l-Arabî, 1405/1985), 2: 59; 'İmâdü'dDîn, Ali b. Muhammed b. Ali Kiyâ el-Herrâsî, Ahkâmu'l-Kur'ân, thk. Mûsâ Muhammed Ali, İzzet Abd Atiyye (Beyrut: Dâru'l-Kütübi'l-İlmiyye, 1405/1985); 1: 169; H. İbrahim Acar, "Talâk", Türkiye Diyanet Vakfı İslâm Ansiklopedisi, (İstanbul: TDV Yayunları, 2010), 39: 499. 
(boşanması) iki defadır, aynı şekilde iddeti de iki hayız dönemidir."72 şeklindeki hadis de bizim İbn Ömer'in kıssasıyla ilgili Buhârî ve Müslim'in rivayet ettiği şu hadise denk değildir: "Abdullâh b. Ömer, hayız döneminde olan eşini boşamış ve babası Hz. Ömer de bu konuda Allah Rasûlünden fetva istemiş. Rasûlullâh ise “Ona söyle eşine dönsün ve eşi tuhr dönemine girdiğinde, o zaman isterse boşar isterse boşamaz. İşte kadınların talâkı (boşanması) ile ilgili Allah Teâlâ'nın emrettiği iddet bu şekildedir."73

Beydâvî'nin hadisler arasındaki denklikten kastettiği, muhtemelen bu hadislerin konuya 1şık tutması ve delil olması yönü itibariyledir.

Burada Beydâvî ve diğer Şâfiîler, "Boşanmış kadınlar kendi kendilerine üç kur' beklerler." (el-Bakara 2/228) âyeti ile yukarıdaki İbn Ömer hadisini bir araya getirerek şöyle bir çıkarımda bulunmuşlardır: "Âyette kadının iddet süresi olarak üç kur'dan bahsedilmektedir. Hadis-i şerifte de eşini hayız döneminde boşayan İbn Ömer'e, eşine dönmesi ve tuhr dönemine girdiğinde boşayabileceği emredilmiştir. Dolayısıyla onlara göre ayette sözü geçen iddet döneminin ilk $k u r^{\prime} u$, hadiste de bildirildiği üzere tuhr dönemi olmaktadır."

Âyet ile hadis arasındaki anlam bütünlüğünden her ne kadar Şâfî̂lerin kastettikleri mana çıkıyorsa da hadisin anlamı bağımsız olarak düşünüldügünde; aslında hadis-i şerifte, sünnete uygun boşamanın nasıl olması gerektiği üzerinde durulmaktadır.

3. Beydâvî'nin ileri sürdüğü diğer bir delil de A'şâ'nın şu şiiridir:

$$
\text { مفري كل عام أنت جاشم غزوة تشد لأقصاها عزيم عزائكا }
$$

Her sene paçaları sıvar gazvelere çıkarsın.

Bu gazvelerden mal ve şöhret elde edersin.

Ancak bu zamanlarda eşlerinin tuhr dönemini zayi edersin. ${ }^{74}$

Beydâvî’nin aktardığı şiirde sözü geçen kişi, zamanlarının çoğunu savaşlarda geçirdiği için eşlerinin tuhr (temizlik dönemlerinde) onlardan faydalanmadığı, dolayısıyla bu dönemleri zâyi ettiği ifade edilmektedir. Görüldügüu üzere bu delil ile Beydâvî, mensubu olduğu Şâfiî mezhebinin görüşüunü ispatlamak maksadıyla Cahiliye şiirinden istişhatta bulunmuştur.

Nesefî de "Boşanmış kadınlar kendi kendilerine üç kur' beklerler." (el-

72 Tirmizî, Sünenü't-Tirmizî, “Talâk”, 7; Beyhâkî, Sünenül-kübrâ, 7: 369; Dârekutnî, Sünenü'dDârekutnî, "Talâk", 1.

73 Buhârî, "Talâk", 1; Beyhâkî, Sünenül-kübrâ, 7: 323; Dârekutnî, Sünenü'd-Dârekutnî, "Talâk”, 1.

74 Beydâvî, Envâru't-tenzîl, thk. Muhammed Abdurrahmân el-Mar'aşlî, 1: 141. 
Bakara 2/228) âyetinde geçen kuru' kelimesini kendi mezhebinin görüşü doğrultusunda yorumlayarak bu kelimenin "hayız/adet dönemleri" anlamında olduğunu ifade etmiştir. Nesefî'nin konu hakkındaki delilleri ise şunlardır:

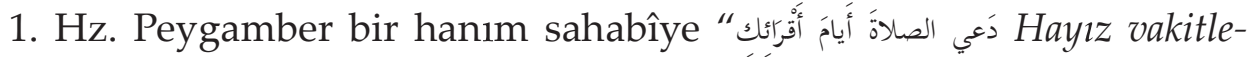
rinde namazı terket!"75 demiştir. Bilindiği üzere namaz, hayız dönemlerinde terkedilir.

2. Bir diğer hadiste de Hz. Peygamber "طاق الأمة تطليتان وعدتها حيضتان Cariyenin talakı (boşanması) iki defadır, aynı şekilde iddeti de iki hayız dönemidir."76 Hadis-i şerifte görüldüğü üzere cariyenin iddeti için "iki hayız dönemi" denilmiş, "iki tuhr dönemi" denilmemiştir.

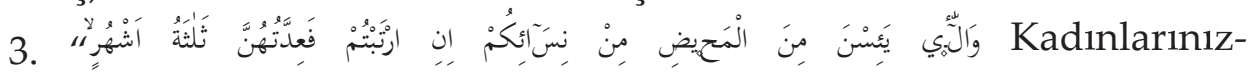
dan ay hali görmekten kesilenlerin iddetleri hususunda şüpheye düşerseniz, bilin ki onların iddet beklemesi üç aydır." (et-Talâk 65/4) âyetinde

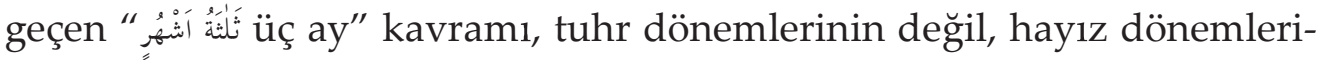
nin mukâbili olarak kullanılmıştır. Zira âyette, boşanmadan sonraki iddet süresiyle amaçlanan şey, kadının rahminin temizlenmesidir. $\mathrm{O}$ da ancak hayız dönemlerinde gerçekleşir.

4. Şâfiîlerin dediği gibi kur', tuhr dönemi olsaydı, boşanmadan sonra kadının bekleyeceği iddet süresi tam olarak üç kur' olmazdı. Çünkü koca, tuhr döneminin sonuna doğru kadını boşarsa, kadın bu durumda iki kur' ve üçüncü kur'un bir kısmını beklemiş olur. Biz de ise (Hanefîlerde) kadın her halukarda üç hayız dönemi bekler. Çünkü "üç" lafzı belirli bir sayı için konulmuş hâss ${ }^{77}$ lafızdır. Üçten daha az bir müddet için "üçc lafzı kullanılmaz. ${ }^{78}$ Aynı şekilde Cessâs da âyetteki kuru' tabirinin "üç" sayısıyla sınırlandığını dolayısıyla daha az olması ihtimalinin bulunmadığını ifade etmektedir. Ona göre de bu tabir, tuhr dönemleri olarak yorumlanırsa, sünnete uygun bir boşamanın gereği olarak tuhr döneminde yapılacak bir talâkta, iddet her durumda eksik kalacak ve "üç" sayısını tam olarak karşılamayacaktır. ${ }^{79}$

Burada Nesefî şunu demek istemektedir: Sünnete uygun boşama, tuhr

${ }^{75}$ Dârekutnî, Sünenü'd-Dârekutnî, “Hayz", 1.

${ }^{76}$ Tirmizî, Sünenü't-Tirmizî “Talâk", 7; Beyhâkî, Sünenül-kübrâ, 7: 369; Dârekutnî, Sünenü'dDârekutnî, "Talâk", 1.

77 Hâss: Tek bir manayı (bu mananın kendisinde gerçekleştiği fertleri) teker teker göstermek üzere konmuş lafızdır. Muhtevasında çokluk manası bulunmakla birlikte çokluğun sınırlı olduğu lafızlar da hâsstır. Dolayısıyla iki, üç, dört, beş gibi sayı isimleri bu kapsama girer. Bk. Şâban, İslâm Hukuk İlminin Esasları, 311; Erdoğan, Fıkıh ve Hukuk Terimleri Sözlü̆̆̈̈̈, 183.

${ }^{78}$ Nesefî, Medârikü't-tenzîl, 1: 189.

${ }^{79}$ Cessâs, Ahkâmu'l-Kur'ân, 2: 59. 
döneminde yapılan boşamadır. Şâfiîlerin dediği gibi kur' kavramını, tuhr dönemi olarak kabul edersek, bu dönemin ortasında veya sonuna doğru boşanan bir kadın için iddet süresi, her durumda üç kur'dan az olur. Çünkü boşanmanın meydana geldiği ilk kur' eksik kalır. Âyette geçen "üç" lafzı ise hâss lafızdır ve bu lafız belirli/sabit bir lafızdır. Dolayısıyla üçten daha az bir müddet için "üç" lafzı kullanılmaz. Hanefîlerde ise durum böyle değildir. Sünnete uygun olarak tuhr döneminde boşanmış bir kadının iddet süresi, ondan sonraki hayız döneminin başlamasıyla başlar ve üç hayız olacak şekilde devam eder. Yani $k u r^{\prime}$ kelimesinin hayız dönemi olarak kabul edilmesi durumunda, bu dönemlerde hiçbir eksiklik meydana gelmez. Netice itibariyle kur' $^{\prime}$ kelimesinin "hayız" olarak kabul edilmesi, hâss olan "üç" lafzının anlamında bir eksiklik meydana gelmemesi bakımından da daha isabetli bir yaklaşımdır.

\section{SONUÇ}

F1khî tefsir metoduna yönelen müfessirler genellikle ahkâm âyetlerinin tefsirinde, fıkıh ilminin usûl ve fürû konularıyla ilgili var olan görüşler üzerinde değerlendirmeler yapmışlardır. Beydâvî ve Nesefî de kendi tefsirlerinde ahkâm âyetleri üzerinde durmuş ve bu âyetlerden çıkarılabilecek hükümler konusunda genellikle mensup oldukları mezheplerin görüşünü tercih etmişlerdir.

Beydâvî, Envârü't-tenzîl'de ahkâm âyetlerini tefsir ederken, çoğunlukla mezheplerin farklı görüşlerini, ileri sürdükleri delillerle birlikte açıklamıştır. Ele aldığ1 meselede genellikle müntesibi olduğu Şâfiî mezhebinin görüşünü tercih ederek, bu görüşü Hanefî mezhebinin görüşüyle karşılaştırmış ve ispatlamak maksadıyla da âyet, hadis, icmâ ve kıyas gibi itibar edilen delillerden yararlanmıştır.

Nesefî de Medârikü't-tenzîl adlı tefsirinin muhtelif yerlerinde fıkıh ilmi kapsamına giren konulara yer vermiştir. Ahkâm âyetlerinin tefsirine büyük önem veren Nesefî, ele aldığı meselede Hanefîlerin dışındaki diğer mezheplerin görüşlerine fazla teferruata girmeden değinmiştir. Ancak müntesibi olduğu Hanefî mezhebinin görüşlerini âyetlerden, hadislerden ve diğer aklî delillerden ispatlamaya çalışmış, diğer mezheplerin görüşlerini reddetmiş̧ir. Bazen de Ebû Hanîfe'nin talebeleri arasında meydana gelen fıkhî ihtilaflara yer vermiştir.

Çalışmadaüzerinde durulan konulardan, Besmele'nin Fâtihâ sûresinden bir ayet olup olmadığı hakkında Beydâvî, Fâtihâ dahil her sûrenin başında gelen Besmele'nin, o sûreye ait müstakil bir ayet olduğunu ifade etmiştir. 
Nesefî ise sûre başlarındaki Besmele'nin ayet olmadığını, bilakis sûrelerin arasını ayırmak ve teberrük için Mushaf'a yazıldığını iddia etmiştir. Yolculukta namazın kısaltılması konusunda ise Beydâvî kısaltmayı caiz görmüş ve bu hükmü ruhsat mesabesinde değerlendirmiştir. Nesefî ise kısaltmanın ruhsat değil vacip olduğunu iddia etmiştir. Aynı şekilde nikah sözleşmesinde, kadın için veli izninin gerekli olduğunu savunan Beydâvî́ye karşılık Nesefi, evlilikte velinin iznine ihtiyaç olmadığını belirtmiştir. Müfessirlerin

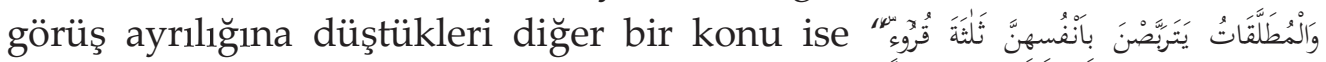
Boşanmış kadınlar kendi kendilerine üç kur' beklerler." (Bakara, 2/228) ayetinde geçen kur $^{\prime}$ kelimesine verilen anlamlar hakkındadır. Beydâvî kendi mezhebinin görüşüne uygun olarak bu kelimenin tuhr (temizlik dönemi) anlamında olduğunu ifade ederken Nesefî, Hanefî mezhebinin görüşü doğrultusunda bunun hayız (adet dönemi) anlamında olduğunu iddia etmiştir.

Hem Envârü't-tenzîl'de hem de Medârikü't-tenzîl'de ilk bakışta göze çarpan bir durum da bu iki tefsir eserinde Arap dili tahlillerine, belâgat inceliklerine ve ara sıra cahiliye şiirinden istişhatlara yer verilmesidir. İki tefsir eserinde mevcut olan bu ortak özellik, ahkâm âyetlerinin tefsirinde de görülmektedir.

\section{KAYNAKÇA}

Acar, H. İbrahim. “Talâk”. Türkiye Diyanet Vakfı İslâm Ansiklopedisi. 39: 496-500. İstanbul: TDV Yayınları, 2010.

Ahmed b. Hanbel, Ebû Abdillâh. Müsnedü'-İmâm Ahmed. Thk. Şuayb el-Arnavûtî 'Âdil Mürşid vd. Beyrut: Müessesetü'r-Risâle, 1421/2001.

Ahmed en-Nükerî. Câmiu'l-'flûm fî̀ ıstılahâti'l-fünûn. Thk. Hasan Hânî Fahs. Beyrut: Dâru'l-Kütübi'l'İlmiyye, 2000.

Bağdatlı İsmail Paşa, Muhammed Emîn el-Bâbânî. Hediyyetül-ârifîn esmâü l-müellifîn ve âsârü'l-musannifinn. İstanbul: MEB Yayınları, 1951.

Bağış, Mehmet. Beydâvî Tefsîri'nde Kur'ân İlimleri ve Tefsir Usûlü. Mardin: Şırnak Üniversitesi Yayınları, 2018.

Bayındır, Abdülaziz. “F1kha Göre Nikâh Sözleşmesinde Velinin Yeri”. İstanbul Üniversitesi İlahiyat Fakültesi Dergisi 4 (2002): 45-67.

Bedir, Murteza. "Nesefî Ebul-Berekât". Türkiye Diyanet Vakfı İslâm Ansiklopedisi. 32: 567-568. İstanbul: TDV Yayınları, 2006.

Beydâvî, Ebû Saîd Nâsıruddîn Abdullâh b. Ömer. Envâru't-tenzîl ve esrâru't-te'vîl. Thk. Muhammed Abdurrahmân el-Mar'aşlî. Beyrut: Dâru İhyâi't-Türâsi'l'Arabî, h. 1418/1997.

Beydâvî, Ebû Saîd Nâsıruddîn Abdullâh b. Ömer. Envâru't-tenzîl ve esrâru't-te'vîll. Thk. Muhammed Subhi b. Hasan Hallâk - Mahmûd Ahmed el-Atraş. Beyrut: Dâru'r-Reşîd, 2000. 
Ahkâm Âyetlerinin Tefsîrinde Mezhebe Bağhllık (Beydâvî ve Nesefî Örneği)

Beydâvî, Ebû Saîd Nâsıruddîn Abdullâh b. Ömer. Gâyetül-kusvâ fi dirâyetil-fetvâ. Thk. Ali Muhyiddîn Ali el-Karadâğî. Beyrut: Dâru'1-Beşâiri'l-İslâmiyye, 2007/1429.

Beyhâkî, Ebû Bekir Ahmed b. Hüseyn b. Ali. Sünenül-kübrâ. Thk. Muhammed Abdülkâdir 'Ata. Beyrut: Dâru'l-Kütübi'l-İlmiyye, 1424/2003.

Beyhâkî, Ebû Bekir Ahmed b. Hüseyn b. Ali. Sünenü's-sağîr. Thk. Abdülmu'tî Emîn Kal'acî. Pakistan: Câmi'atü'd-Dirâsâti'l-İslâmiyye, 1989/1410.

Beyhâkî, Ebû Bekir Ahmed b. Hüseyn b. Ali. Şu'abu'l-îmân. Thk. Muhammed Saîd Besyûnî, Zağlûl. Beyrut: Dâru'l-Kütübi'l-İlmiyye, h. 1410.

Buhârî, Ebû Abdillâh Muhammed b. İsmâîl. el-Câmi'ü's-sahîh el-muhtasar. Thk. Mustafa Dîb el-Buğâ. Beyrut: Dâru İbn Kesîr-Yemâme, 1407/1987.

Cerrahoğlu, İsmail. Tefsir Tarihi. 6. Baskı. Ankara: Fecr Yayınları, 2014.

Cessâs, Ebû Bekr Ahmed b. Ali er-Râzî. Ahkâmül-Kur'ân. Thk. Muhammed Sâdık el-Kamhâvî. Beyrut: Dâru İhyâi't-Türâsi'l-Arabî, h. 1405.

Çetiner, Bedreddin. "Ahkâmü'l-Kur'an". Türkiye Diyanet Vakfı İslâm Ansiklopedisi. 1: 551-552. İstanbul: Türkiye Diyanet Vakfı Yayınları, 1988.

Dârekutnî, Ebu'l-Hasen Ali b. Ömer. Sünenü'd-Dârekutnî. Thk. Seyyid Abdullâh Hâşim. Beyrut: Dâru'l-Ma'rife, 1966/1386.

Dâvûdî, Şemsüddîn, Muhammed b. Ali. Tabakâtül-müfessirîn. Beyrut: Dâru'lKütübi'l-İlmiyye, ts.

Demirci, Muhsin. Tefsir Tarihi. İstanbul: İFAV Yayınları, 2010.

Ednevî, Ahmed b. Muhammed. Tabakâtül-müfessirîn. Thk. Süleymân b. Sâlih elCezzî. Suudi Arabistan: Mektebetü'l-‘Ulûm, 1997/1417.

Erdoğan, Mehmet. Fıkıh ve Hukuk Terimleri Sözlüğü. İstanbul: Ensar Neşriyat, 2016.

Güngör, Mevlüt. Kur'ân Tefsirinde Fıkhi Tefsir Hareketi ve İlk Fıkhi Tefsir. İstanbul: Kur'ân Kitaplığı, 1996.

Hafâcî, Şihâbüddîn Ahmed b. Muhammed. Hâşiyetü'ş-Şihâb alê tefsîril-Beydâvîl İnâyetü'l-Kâdî ve kifâyetü'r-Râdî. Beyrut: Dâru'l-Kütübi'l-İlmiyye, 1997/1417.

Hamevî, Yâkût b. Abdullah. Mu'cemül-büldân. Beyrut: Dâr Sâdır, 1995.

İbn Ebî Şeybe, Ebû Bekir Abdullâh b. Muhammed. Kitâbül-Musanneffi'l-ehâdîs velâsâr. Thk. Kemâl Yûsuf el-Hût. Riyad: Mektebetü'r-Rüşd, h. 1409.

İbn Manzûr, Muhammed b. Mukrim b. Ali Ebu'l-Fadl Cemâlüddîn. Lisânu'-Arab. Beyrut: Dâr Sâdır, h. 1414.

İbn Rüşd, Ebu'l-Velîd Muhammed b. Ahmed b. Muhammed b. Ahmed el-Kurtubî. Bidâyetül-müctehid ve nihâyetü'l-muktesıd. Kâhire: Dâru'l-Hadîs, 2004.

İbnü'-İmâd, Ebû'1-Felâh 'Abdü'l-Hayy b. Ahmed b. Muhammed. Şezerâtü'z-zeheb fi ahbâri men zeheb. Thk. Mahmud el-Arnavût. Şâm: Dâru İbn Kesîr, 1406/1986.

İman ve İbadetler/İlmihal. Ankara: DİB Yayınları, 2006.

Kâdî Şuhbe, Takiyyüddîn Ebû Bekir b. Ahmed. Tabakâtü'ş-Şâfi'iyye. Thk. Hâfız Abdül'alîm Hân. Beyrut: Âlemü'l-Kütüb, h. 1407.

Kâtip Çelebi, Mustafa b. Abdullah Hâcı Halîfe. Keşfu'z-zunûn 'an esâmi't-kütüb ve lfünûn. Bağdat: Mektebetü'1-Müsennâ, 1941.

Kiyâ el-Herrâsî, 'İmâdü'd-Dîn Ali b. Muhammed b. Ali. Ahkâmü̈l-Kur'ân. Thk. Mûsâ Muhammed Ali, İzzet Abd Atiyye. Beyrut: Dâru'l-Kütübi'l-İlmiyye, h. 1405. 
Kurtubî, Ebû Abdillâh Muhammed b. Ahmed b. Ebî Bekr el-Hazrecî. el-Câmi'u li ahkâmi'-Kur'ân. Thk. Ahmed el-Berdûnî - İbrâhîm Atfîş. Kâhire: Dâru'lKütübi'l-Misriyye, 1384/1964.

Mavil, Kılıç Aslan. "Bir Hanefî-Mâtürîdî Âlimi Ebu'l-Berekât en-Nesefî”. Uludă̆g Üniversitesi İlahiyat Fakültesi Dergisi 22/1 (2013): 57-83.

Merğînânî, Burhânüddîn Ali b. Ebî Bekr b. Abdilcelîl el-Ferğânî. el-Hidâye fì Şerhi Bidâyeti'-mübtedî. Thk. Talâl Yûsuf. Beyrut: Dâru İhyâi't-Türâsi'l-'Arabî, ts.

Molla Hüsrev. Mirkâtül-vüsûl Tercümesi ve Şerhi. Çev. Haydar Sadıkoğlu. İstanbul: Özgü Yayıncilık, 2014.

Muhammed Naîm Muhammed Hânî Sâ'î. Mevsu'atü mesâilil-cumhûr fi'l-fikhilİslâm. Misır: Dâru's-Selâm, 1428/2007.

Münâvî, Zeynüddîn Muhammed Abdurraûf. Fethü's-semâvî bi tahrîci ehâdîsi'-Kâdı Beydâvî. Thk. Ahmed Müctebâ. Riyad: Dâru'l-'Âsime, ts.

Müslim b. Haccâc Ebu'l-Hasen el-Kuşeyrî. Sahîhu Müslim. Thk. Muhammed Fuâd Abdülbâkî. Beyrut: Dâru İhyâi't-Türâsi'l-'Arabî, ts.

Nesefî, Hâfizuddîn Ebu'l-Berekât Abdullah b. Ahmed b. Mahmûd. Medârikü't-tenzîl ve hakâikü't-te'vîl. Thk. Yusuf Ali el-Bedevî. Beyrut: Daru'l-Kalem, 1998/1419.

Râğıb el-Isfahânî, Ebu'l-Kâsım el-Huseyn b. Muhammed. el-Müfredât fî̀ garîbilKur'ân, Thk. Safvân Adnân ed-Dâvudî, Dimeşk - Beyrut: Dâru'l-Kalem Dâru'ş-Şâmiyye, h. 1412.

Sâbûnî, Muhammed Ali. Ravâiu'-beyân tefsîru âyâti'l-ahkâm. Dimeşk: Mektebetü'1Gazâlî, 1980/1400.

Serahsî, Şemsü'l-Eimme Muhammed b. Ahmed b. Ebî Süheyl. el-Mebsût. Beyrut: Dâru'l-Ma'rife, 1993/1414.

Sübkî, Tâcüddîn Abdülvehhâb. Tabakâtü'ş-Şâfi'iyyeti'l-kübrâ. Thk. Mahmud Muhammed et-Tanâhî - Abdülfettâh Muhammed el-Hulv. B.y. Dâru'l-Hicr, h. 1413.

Şâfiî, Ebû Abdillâh Muhammed b. İdrîs b. Abbâs b. Osmân b. Şâf'i. el-Ümm. Beyrut: Dâru'l-Ma'rife, 1990.

Taberânî, Ebu'l-Kâsım Süleymân b. Ahmed. Mu'cemu'l-kebîr. Thk. Hamdi b. Abdülmecîd es-Selefî. Kâhire: Mektebetü İbn Teymiye, 1994/1415.

Tehânevî, Muhammed b. Ali. Mevsûatü keşşâfi ıstılâhatil-fünûn ve'l-ulûm. Thk. Ali Dahrûc. Beyrut: Mektebetü Lübnân Nâşirûn, 1996.

Tirmizî, Muhammed b. İsa. Sünenü't-Tirmizî. Thk. Ahmed Muhammed Şâkir - Muhammed Fuad Abdülbâkî - İbrahim Utva. Mısır: Mektebetü ve Matbaatu Mustafa el-Bâbî, 1395/1975.

Türk Hukuk Lûgatı. Ankara: Başbakanlık Basımevi, 1998.

Yüksel, Yakup. "Beydâvî Tefsiri'nde Besmele Tahlili". Sakarya Üniversitesi İlahiyat Fakültesi Dergisi 14/26 (2012/2): 91-107.

Yüksel, Yakup. “Fıkhî Tefsir Geleneğinde 'Ahkâm-1 Kur'aniyye'nin Yeri”. Gümüşhane Üniversitesi İlahiyat Fakültesi Dergisi 4/8 (2015/4): 161-181.

Zehebî, Muhammed Hüseyn. et-Tefsîr ve' l-müfessirûn. Kâhire: Mektebetü Vehbe, ts.

Zekiyüddîn Şâban, İslâm Hukuk İlminin Esasları. Çev. İbrahim Kâfi Dönmez. Ankara: TDV Yayınları, 2018. 